\title{
Thinned continental crust intruded by volcanics beneath the northern Bay of Bengal
}

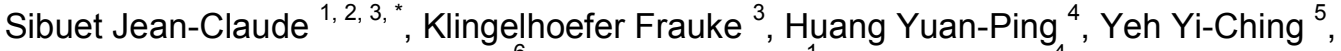 \\ Rangin Claude ${ }^{6}$, Lee Chao-Shing ${ }^{1}$, Hsu Shu-Kun ${ }^{4}$
}

\author{
${ }^{1}$ Institute of Applied Geophysics, National Taiwan Ocean University, 2 Pei-Ning Road, Keelung 202, \\ Taiwan \\ ${ }^{2} 44$ rue du Cloître, 29280 Plouzané, France \\ ${ }^{3}$ Ifremer, Centre de Brest, BP 70, 29280 Plouzané Cedex, France \\ ${ }^{4}$ Department of Earth Sciences, National Central University, Chung-Li 320, Taiwan \\ 5 Taiwan Ocean Research Institute, 219, Sec. 1 Dongfang Rd., Qieding Dist., Kaohsiung 852, Taiwan \\ ${ }^{6}$ Laboratoire GEOAZUR, UMR 7329 CNRS, 250 rue Albert Einstein, Sophia-Antipolis, 06560 Valbonne, \\ France \\ * Corresponding author : Jean-Claude Sibuet, email address : jean.claude.sibuet@gmail.com \\ frauke.klingelhoefer@ifremer.fr ; janushuang711@gmail.com ; ycyeh@narlabs.org.tw ; \\ rangin@geoazur.unice.fr ; leecs@ntou.edu.tw ; hsu@ncu.edu.tw
}

\begin{abstract}
:
Since the early Cretaceous, the Bay of Bengal was formed during rifting between India and Antarctica and then by subsequent seafloor spreading. The nature of the crust underlying the Bay of Bengal is oceanic south of $15^{\circ} \mathrm{N}$, but remains unknown (thinned continental crust, serpentinized mantle or oceanic crust) north of this limit. In order to better define the nature of the crust in the northern Bay of Bengal, three wide-angle reflection seismic and refraction profiles were acquired during the multichannel seismic reflection Bengal cruise. Nine ocean-bottom seismometers were deployed alternatively on three profiles. A seismic source consisting of 64 air guns with a volume of 6180 in 3 was used simultaneously with a $10.05-\mathrm{km}$ long streamer to acquire both seismic reflection and refraction data. Tomographic and forward modeling of the three refraction profiles reveal a $20-\mathrm{km}$ thick crust north of the Bengal delta front beneath a minimum of $13 \mathrm{~km}$ thick sedimentary cover. The crust thins to about $10 \mathrm{~km}$ immediately south of the EW trending delta front and the thickness of sediments reaches a minimum of $7 \mathrm{~km}$. Crustal velocities and velocity gradients are consistent with a continental origin of the crust in this area. At the base of the crust, high seismic velocities $(>7.2 \mathrm{~km} / \mathrm{s})$ are interpreted as magmatic underplating. Wideangle seismic reflection and refraction data cannot resolve the nature of the upper $4-5 \mathrm{~km}$ of crust (oceanic crust, exhumed mantle or thinned continental crust). Coincident seismic reflection profiles show the emplacement of a volcanic intrusion, sills and some seaward dipping reflectors (SDRs) located close to the northern prolongation of the Ninety East ridge before $70 \mathrm{Ma}$ (Maastrichtian). However, most of the fan-shaped reflectors identified in the northern Bay of Bengal are synrift features. We conclude that the crust in the northern Bay of Bengal is thinned continental crust intruded by volcanic products with the presence of a minor amount of underplating material at its base. Such a crustal structure probably extends from the northern Bay of Bengal $\left(19^{\circ} \mathrm{N}\right)$ to the Shillong Plateau $\left(25^{\circ} \mathrm{N}\right)$. These new findings are critical for the oil and gas exploration presently very active in the
\end{abstract}


northern Bay of Bengal area.

\section{Highlights}

- Refraction velocity models show a sedimentary cover of $13 \mathrm{~km}$ minimum beneath the shelf and $7 \mathrm{~km}$ minimum beneath the deep ocean. The crust is thinned continental crust, $10-20 \mathrm{~km}$ thick. The thinned continental crust is intruded by volcanics, sills and SDRs. Seismic velocities of $7.4 \mathrm{~km} / \mathrm{s}$ found at the base of the crust is interpreted as magmatic underplating. The thinned continental crust extends from $19^{\circ} \mathrm{N}$ (northern Bay of Bengal) to $25^{\circ} \mathrm{N}$ (Shillong Plateau).

Keywords: Northern Bay of Bengal, Wide-angle seismic reflection and refraction data, Thinned continental crust intruded by volcanics 


\section{ACCEPTED MANUSCRIPT}

The study of passive continental margins is of interest for understanding the processes of rifting and margin formation, as well as the evolution of associated sedimentary basins. A combination of wide-angle seismic modeling with seismic reflection data can give information about the nature and thickness of the crust as well as the depositional history of the studied region, providing valuable answers to questions concerning the rifting processes followed by the opening of a new ocean.

To the west and north, the Bay of Bengal $(\mathrm{BoB})$ is bordered by the passive continental margins of India and Bangladesh and to the east by the West Sunda plate wrench zone (Rangin et al., 2013), active since 20 Ma but generally interpreted in the literature as an oblique subduction zone (Figure 1). The large sedimentary thickness in the BoB is linked to the high influx of sediments transported by the Ganges and the Brahmaputra rivers and was previously estimated to be up to $12 \mathrm{~km}$ (Curray and Moore, 1971). Results from earlier wideangle seismic reflection and refraction data show sedimentary thicknesses of up to $9 \mathrm{~km}$ in the northern BoB reduced to 3-4 km in the southern part (Naini and Leyden, 1973; Curray et al., 1982; Subrahmanyam and Singh, 1992). Beneath sediments, the crustal thickness in the northern part of the Bob was not constrained probably because of the large amount of sediments. Based on isostatic calculations, Curray (1994) proposed a balanced oceanic crust of $3.0 \mathrm{~g} / \mathrm{cm}^{3}$ below $22 \mathrm{~km}$ of sediments. To the north, in the onshore Bengal Basin, Verma and Mukhopadhyay (1977) and Uddin and Lundberg (2004) suggested the existence of a thick and dense oceanic crust and at the base of the crust, Mall et al. (1999) observed a high velocity layer (> $7.5 \mathrm{~km} / \mathrm{s}$ ) interpreted as volcanic underplating. From 3-D gravity modeling in the Bay of Bengal, Radhakrishna et al. (2010) propose a thin oceanic crust. Consequently, if the oceanic nature of the crust seems to be reasonably established south of $15^{\circ} \mathrm{N}$ (Curray et al., 1982), where the basin is floored by a 5-6 km thick oceanic crust (Subrahmanyam and Singh, 1992), there is a complete disagreement concerning the nature and thickness of the crust in the northern offshore and onshore Bay of Bengal.

The major objective of the Bengal cruise seismic refraction study was to determine the nature and origin of the crust in the northern part of the BoB. Knowing the difficulty to image the lower part of a basin with a so large thickness of sediments and to define the thickness and nature of the underlying crust, we operated a state-of-the-art industry seismic vessel and a second vessel to deploy ocean bottom seismometers (OBSs) along critical profiles both perpendicular and parallel to the Bangladesh margin. This paper presents the interpretation of the wide-angle seismic reflection and refraction data collected along coincident multi-channel seismic (MCS) profiles. A second paper deals with the age and deformation style of the 
northern Bengal Basin floor (Rangin et al., 2016 submitted) and a third paper with the structural and kinematic evolution of the Bay of Bengal (Sibuet et al., in preparation).

\section{Data processing}

During the Bengal cruise (Dec. 12, 2007-Jan. 6, 2008), $3500 \mathrm{~km}$ of MCS data were acquired by the R/V Osprey Explorer (Figure 1) using a $10.05 \mathrm{~km}$ long streamer with 804 channels, towed at a water-depth of $8 \mathrm{~m}$ and with a shooting interval every $50 \mathrm{~m}$. The seismic source was a $6180 \mathrm{in}^{3}$ tuned air-gun array of 64 air-guns towed at a depth of $8 \mathrm{~m}$. Wide-angle seismic reflection and refraction data were acquired along three MCS profiles (Figure 2). Nine OBSs were deployed along each of the three profiles with a $20-\mathrm{km}$ distance between OBSs. The instruments (Auffret et al., 2004) were provided by the National Taiwan Ocean University (NTOU) and recorded on four channels (1 hydrophone and 3 geophones), using a 4-ms sampling interval. 13,207 shots were fired along the three OBS profiles. Data quality is very good with clear PmP arrivals from the Moho, as shown in Figures 3a and 4a.

Data of all seafloor instruments were corrected for the time drift of the internal clock immediately after retrieval. As the instruments drift during their travel to and from the seafloor, their positions were corrected using the direct water arrival phases. To avoid timing errors, the picking of the travel-time arrivals was performed, as much as possible, without filtering the data. Different filters were used for long offset arrivals. Most travel-time arrivals were picked on the geophone sections. The hydrophone data were used for picking when displaying higher quality than the geophone data, which however was rarely the case.

\subsection{Velocity modeling}

A preliminary model of seismic velocities was obtained by using only the first arrivals with the tomographic code FAST (First Arrival Seismic Tomography) (Zelt and Barton, 1998). These models give a first and user-independent image of the main structures. Then, the software package Rayinvr (Zelt and Smith, 1992) was used to construct forward models, including travel-time picks from secondary arrivals and from MCS data. The final models were additionally constrained by gravity modeling and by the computation of synthetic data (Zelt and Smith, 1992).

The first tomographic models established with the FAST code (Figure 5) served later on as rough guidelines for the forward modeling. The non-linear tomographic calculation 
consists in a regularized inversion where user specified parameters weight the final solution in terms of travel-time misfit and model roughness. Employing iterative convergence scheme was a linear process but calculating new ray paths for each iteration was not a linear process. This method generated smooth models, which resolve steeper velocity gradient without sharp boundaries. The most important structural features are resolved in an objective manner. Along the three profiles, a total of 38,621 travel-times picks were used to perform the tomographic inversion model. Each pick has been assigned a picking error around $100 \mathrm{~ms}$ depending on the data quality. Each model used a 1-km grid cell size. The three final models are characterized by root mean square (rms) travel-time misfits of 132, 128 and $174 \mathrm{~ms}$.

The Program Rayinvr (Zelt and Smith, 1992) was used for forward modeling of the wide-angle seismic reflection and refraction data (Figure 6). 18,099 travel-time picks were included into the modeling of Profile 2. For the model parameterization, we used the minimum-parameter/minimum-structure approach, to avoid inclusion of velocity or structural features into the model unconstrained by the data (Zelt, 1999). One exception was that the main sedimentary interfaces were picked from the reflection seismic data and included into the velocity model using velocities obtained from the OBS data. Modeling was performed using a layer-stripping approach from the top of the structure to the bottom. A twodimensional iterative damped least-squares inversion of the travel-times, which is part of the Rayinvr package, was additionally used for the deeper parts, which are unconstrained by MCS data.

All three models are composed of eight different layers separated by black lines (Figure 6): the water layer, four sedimentary layers, a high impedance layer corresponding to either the acoustic basement or the top of a volcanic layer, a crustal layer and an upper mantle layer. The depth and velocity nodes define each layer. The water velocity is between 1.5 1.53 $\mathrm{km} / \mathrm{s}$ for the three profiles (Figure 6).

On Profile 2, seismic velocities vary in sedimentary layers from $1.75 \sim 2.0 \mathrm{~km} / \mathrm{s}$ for the upper layer to $2.14 \sim 3.84 \mathrm{~km} / \mathrm{s}, 4.2 \sim 4.4 \mathrm{~km} / \mathrm{s}$ and $4.4 \sim 4.9 \mathrm{~km} / \mathrm{s}$ for the underlying layers. The acoustic basement layer is characterized by a velocity of $4.9 \sim 5.2 \mathrm{~km} / \mathrm{s}$. The crustal layer shows velocities between $6.4 \sim 7.4 \mathrm{~km} / \mathrm{s}$. The upper mantle velocity was constrained to be 7.9 to $8.1 \mathrm{~km} / \mathrm{s}$ by Pn arrivals.

Profile 11 was shot in shallow water. Velocities of the four sediment layers on profile 11 are $1.75 \sim 2.0 \mathrm{~km} / \mathrm{s}, 2.6 \sim 3.8 \mathrm{~km} / \mathrm{s}, 4.1 \sim 4.7 \mathrm{~km} / \mathrm{s}$ and $4.6 \sim 5.0 \mathrm{~km} / \mathrm{s}$. On this profile, the acoustic basement layer was modeled using a velocity of $5.1 \sim 5.4 \mathrm{~km} / \mathrm{s}$. The velocity of crustal 
layer is $6.4 \sim 7.4 \mathrm{~km} / \mathrm{s}$ and the underlying upper mantle is characterized by a velocity of 8.1 $\mathrm{km} / \mathrm{s}$.

On Profile 5, perpendicular to the shelf break, the four sedimentary layers display velocities of $1.85 \sim 2.0 \mathrm{~km} / \mathrm{s}, 2.4 \sim 3.2 \mathrm{~km} / \mathrm{s}, 4.2 \sim 4.5 \mathrm{~km} / \mathrm{s}$ and $4.6 \sim 4.8 \mathrm{~km} / \mathrm{s}$. The velocity of the acoustic basement layer is $5.1 \sim 5.4 \mathrm{~km} / \mathrm{s}$. The crustal layer displays velocities between 6.1 and $7.35 \mathrm{~km} / \mathrm{s}$. The upper mantle is characterized by velocities about $8.1 \mathrm{~km} / \mathrm{s}$.

Arrivals from sedimentary and crustal layers picked from OBS data are illustrated in Figure 7 by showing ray paths for every $40^{\text {th }}$ ray separately for diving and reflected rays for all three profiles. The corresponding travel-time picks and predicted arrivals shows the reliability of the model interfaces displayed in Figures 5 and 6.

\subsection{Error analysis}

The difference between the observed and predicted arrival times is a measurement of the quality of the model. The number of picks and rms travel-time residuals for all phases are listed in Table 1.

The ray density is a measurement of the number of rays passing through each cell of the model. In all three models the ray density is high, which is also due to the small shot spacing (Figure 8). The highest values are found in the sedimentary and upper crustal layers. Ray density in the lower crust is significantly reduced. The ends of profiles are less covered than the central parts.

The resolution of forward models is calculated from the number of rays passing each node. If values are smaller than 0.5 , the layer is not well constrained. If values are larger than 0.5 , the layer is considered to be well constrained. The resolution used and explained in this work depends primarily on the number of nodes used for each layer and the number of rays crossing this given node. Low resolution means that too many velocity nodes have been included in a given layer. This is different from tomographic approaches, where resolution depends on the cell size. Results from the resolution analysis show that most of the sedimentary and crustal layers are well constrained (Figure 9). As the resolution parameter is higher than 0.5 , we can conclude that only the necessary minimum of nodes were included into the models. Resolution does not reach values lower than 0.5 at the ends of the profiles, if only a laterally constant velocity gradient is used for one layer, as all rays penetrating the layer pass by those nodes. 
In order to constrain the velocity gradients in the different layers, synthetic seismograms were calculated and compared to the data sections. The finite difference modeling code of the Seismic Unix package (Stockwell, 1999; Cohen and Stockwell, 2003) was used to calculate synthetic seismograms of a record length of $30 \mathrm{~s}$ at 100-m spacing (Figures $3 \mathrm{~b}$ and $4 \mathrm{~b}$ ). The program uses the explicit second-order differencing method for modeling the acoustic wave equation. The input velocity model was calculated from sampling the forward velocity model at a 50-m horizontal interval and a 10-m interval in depth. In order to avoid grid dispersion, the peak frequency of the Ricker wavelet source signal is calculated to be equal to the lowest velocity of the medium divided by the grid points per wavelength multiplied by 10 . In this case, the source wavelet is centered at $8 \mathrm{~Hz}$, similar to the frequency signal of the air-gun array used during the Bengal cruise. The boundary conditions were set up to be absorbing at the sides and bottom of the model and free at the surface.

\subsection{Gravity modeling}

Gravity modeling was used to additionally constrain the velocity models, especially in the areas unconstrained by seismic data. The seismic velocities were converted to densities using the relationship of Ludwig et al. (1970). Densities in the mantle were set to a constant $3.32 \mathrm{~g} / \mathrm{cm} 3$ and the models were extended to a depth of $125 \mathrm{~km}$ and laterally to a distance of $100 \mathrm{~km}$ on each side of the model. The predicted anomaly from the density models was calculated every kilometer and a constant value was added to improve the fit between the calculated and measured gravity anomaly. The resulting predicted anomalies closely match the observed anomalies (Figure 10). Small discrepancies between the two curves can be explained by either 3-D effects or imprecisions in the velocity-density relationship.

\subsection{Comparison with MCS profiles}

In order to verify the good fit between forward velocity models and coincident MCS data, the velocity model layers were converted to two-ways travel-times and overlain onto the MCS data sections (Figure 11). As layers have been picked using the MCS data as a guideline, the fit is very good for the sedimentary sections above the basement. Basement and Moho reflections are scarcer in the MCS data section and therefore are based on OBS data modeling only. 


\section{Results and discussion}

\subsection{Velocity structure in the northern Bay of Bengal}

The final velocity models obtained by forward modeling show a thick sedimentary cover along the three profiles, decreasing from $13 \mathrm{~km}$ below the shelf to $7 \mathrm{~km}$ towards the southeast. These values are minimum values for the thickness of sediments because synrift sediments are not specifically imaged on the refraction data of Figures 5 and 6 . Four distinct layers have been modeled with velocities increasing from $1.80 \mathrm{~km} / \mathrm{s}$ to $4.80 \mathrm{~km} / \mathrm{s}$. These sediments, originated from erosion of the Himalaya and transported by turbidity currents along meandering fan valleys, are part of the Bengal fan and have been mapped further south (Curray and Moore, 1971).

In order to constrain the nature of the crust along the three wide-angle seismic reflection and refraction profiles, velocity-depth profiles were extracted every $10 \mathrm{~km}$ along the three profiles and compared to normal oceanic crust (White et al., 1992), exhumed mantle (Dean et al., 2000) and thinned continental crust (Christensen and Mooney, 1995) (Figure 12). The basement is assumed to correspond to the top of the 6.2 to $7.4 \mathrm{~km} / \mathrm{s}$ layer. Clearly, all the resulting velocity-depth profiles show a crustal thickness varying between 10 and $20 \mathrm{~km}$ with low velocity gradients comparable to those of thinned continental crust (Christensen and Mooney, 1995).

In comparison, the typical oceanic crust is only about 7-km thick and divided into two layers. The upper layer 2, between 2 and $3 \mathrm{~km}$ thick is characterized by high velocity gradients and the lower layer around 5-km thick is characterized by a relatively lower velocity gradient. Despite the existence of two crustal layers, the relative crustal thickness and the observed velocity gradients do not match those of oceanic crust.

In the ocean-continent transition zone of some passive continental margins, a region of exhumed and subsequently serpentinized upper mantle material is found (e.g. Dean et al. (2000), Funk et al. (2004) and Lau et al. (2006). This crust is characterized by seismic velocities ranging between $4.6 \mathrm{~km} / \mathrm{s}$ corresponding to a high degree of serpentinization and $7.8 \mathrm{~km} / \mathrm{s}$ corresponding to nearly unaltered mantle material. Reflections from the base of the serpentinized layer are either absent (Funk et al., 2004) or extremely weak (Lau et al., 2006). Seawater descending into the mantle through deep faults is proposed to be at the origin of the serpentinization process. If the relatively high velocities at the base of the crust might be theoretically explained by serpentinized upper mantle material, the thickness of the crust in 
the northern $\mathrm{BoB}$ is probably too large to allow the seawater to follow deep crustal faults to these depths. In addition, lower crustal computed velocities are outside the exhumed serpentinized bounds (Dean et al., 2000), which appear in Figure 12, suggesting that serpentinized peridotites are absent in the lower crust.

Only the seismic velocities of $7.4 \mathrm{~km} / \mathrm{s}$ found at the base of the crustal layer do not agree with a continental origin because continental crust at a depth of 30-35 km displays seismic velocities lower than $7.0 \mathrm{~km} / \mathrm{s}$ (Christensen and Mooney, 1995). A possible explanation of the high velocities at the base of the crust is the presence of magmatic underplating. The high-velocity material might correspond to gabbro sills alternating with dunites (Canales et al., 2000) or to olivine-rich gabbros resulting from fractionation of basaltic melt in crustal magma chambers (Farnetani et al., 1996)). Such underplated material is frequently found on volcanic margins (e.g. (Morgan and Barton, 1990; Klingelhoefer et al., 2005)), at the base of volcanic islands (e.g. (Watts et al., 1985; Caress et al., 1995)) but also at the base of highly thinned continental crust (Sibuet et al., 1995). In the northern BoB, where the crust is already largely thinned (from $20 \mathrm{~km}$ along profile 11 to $10 \mathrm{~km}$ to the south of the refraction survey), we thus favor the presence of underplated material rather than serpentinized mantle peridotites at the base of the crust as previously discussed. In our refraction data (Figure 6), the Moho discontinuity is associated with a mean 7.4-8.1 km/s velocity drop and is identified in some places on MCS Profile 5 (Figure 13). It is also an argument against the presence of serpentinized mantle never associated in the literature with a significant drop in seismic velocities and consequently with the presence of a Moho discontinuity. This interpretation is also in good agreement with seismic data collected in the onshore Bengal Basin, which indicate the presence of a 3-5 km thick layer of underplated material (Mall et al., 1999). Therefore, our preferred interpretation is that the crust in the northern $\mathrm{BoB}$ is thinned continental crust intruded by volcanic products with the presence of a minor amount of underplating material at its base. These new findings are critical for the oil and gas exploration in this area.

\subsection{Nature of the crust in the northern Bay of Bengal}

If the crust of northern $\mathrm{BoB}$ is thinned continental crust, the nature of the upper 3-4 km of crust cannot be resolved by refraction velocities because these velocities are in the range of those of oceanic layer 2, exhumed mantle and thinned upper continental crust. However, an oceanic nature of the upper part of the crust is impossible, as oceanic crust cannot lie over an 
existing thinned continental crust. Similarly, even if underplating exists at the base of the crust, it is impossible to emplace at a large-scale serpentinized mantle on top of a 10 to $20 \mathrm{~km}$ thick continental crust. Thus, the whole crust, including the upper $3-4 \mathrm{~km}$, is thinned continental crust.

Figure 13 shows MCS Profile 5 and its interpretation as well as the location of two blow-ups, which will be used to discuss the nature of the upper part of the crust and overlying sediments. Note that the reflection Moho determined from MCS data is coincident with the refraction Moho determined from refraction data.

The green reflector in Figure 13 is the top of a thin but highly reflective series of horizons (as evidenced on the true amplitude recovery and automatic gain control of Figures 14 and 15 blow-ups), which is an indiscutable marker well recognized in the whole Bay of Bengal. Seismic velocities close to $5.0 \mathrm{~km} / \mathrm{s}$ are higher than commonly found for sediments and might correspond to either highly compacted sediments or a hard ground formed during the late Cretaceous drift of the Bengal Basin attached to India with respect to Antarctica. This series of reflectors has been drilled at DSDP Site 217 (Moore et al., 1974) where nanno-chalk, cherts and porcellanite dated Campanian to Paleocene with a mean Maastrichtian age were recovered. This pelagic sedimentary sequence is similar to the porcellanite and siliceous limestones accreted in the southern Arakan range in Myanmar and dated Maastrichtian (latest Cretaceous) on the presence of Globotruncana species (Maurin and Rangin, 2009).

Figure 14 shows a 40-km wide volcanic intrusion emplaced on top of the thinned continental crust and characterized by a reflector upturn at a depth of $8 \mathrm{~s}$ near a distance of 24 $\mathrm{km}$. The shape of the volcanic body in the lower continental crust is hypothetical and might be eventually reduced to the size of a feeding channel. The body with a triangular shape located to the SSW of the volcanic intrusion is probably an intruded sill through the postrift sediment sequence, which is at least 1.5 second two-way travel time (TWTT) thick below the green reflector. A second sill is also identified on the NNE side of the volcanic body and is also intruded through the horizontal postrift sediment sequence at least 1.0 second TWTT thick below the green reflector. At its southward intersection with the volcanic body, the green reflector is $0.15 \mathrm{~s}$ uplifted. Uplift of the overlying sedimentary reflectors progressively decreases with depth in the direction of the tip of the SSW sill. The upward convexity of reflectors younger than the green reflector and located above the volcanic body seems to be linked to differential pelagic sedimentation. As sedimentary reflectors are not tectonically uplifted above the green reflector and as onlaps are observed on top of the green reflector (Figure 14), the emplacement of sills occurred before the time of deposition of the green 
reflector (Campanian to Paleocene, mid age Maastrichtian, $70 \mathrm{Ma}$ ). The regional flexure is related to the presence of the volcanic load above an already existing thinned continental crust lying on a lithosphere heated by the underlying Kerguelen hotspot when it was below the northern BoB, about 100 Ma ago (Muller et al., 1993; Whittaker et al., 2013). Thus, the volcanic intrusion and associated sills were emplaced sometime during the 70 to $100 \mathrm{Ma}$ period during which the deposition of the at least $1.5 \mathrm{~s}$ TWTT of horizontally deposited postrift sediments occurred.

An important question is the nature of fan-shaped reflectors, which appear in the second blow-up (Figure 15). Are they synrift fan-shaped sedimentary reflectors located in between tilted fault blocks belonging to the upper thinned continental crust or are they deep SDRs? The geometry of the dipping reflectors shows a divergent system in direction of the SSW part of Profile 5 without clear onlaps of these reflectors between them. Profile 5 being oriented NNE-SSW, the magmatic source may be the N-S oriented Ninety East ridge. This observation, combined with the fact that the fan-shaped reflectors are close to the volcanic intrusion and the identified sills, suggest that they may be SDRs. In addition, the top of the dipping reflectors is located just below the green reflector, suggesting they were emplaced at the same time that the nearby volcanic intrusion and sills of Figure 14, located in the close vicinity of the northward extension of the Ninety East ridge. Therefore, we interpret the dipping reflectors observed on Profile 5 as volcanic SDRs rather than fan-shaped synrift deposits.

Such fan-shaped reflectors have been observed on all profiles of the Bengal cruise (Figures 1 and 2) (Rangin et al., 2016 submitted). Most of them are dipping to the southeast and are difficult to interpret as SDRs because their source would be from the west and not from the east where is located the Ninety East ridge, considered as a reasonable potential magmatic source. These fan-shaped reflectors seem to be rather linked to NE-SW features interpreted by Rangin et al. (2016 submitted) as tilted blocks. However, a few of these fanshaped reflectors, including those on Profile 5, have been interpreted as SDRs with the Ninety East ridge as magmatic source (Rangin et al., 2016 submitted). We conclude that the fanshaped reflectors observed in the northern BoB may be both SDRs in the close vicinity of the Ninety East ridge (Figure 15) and synrift reflectors in the rest of the Bengal survey. This situation present similarities and differences with the Pelotas and Santos basins offshore Brazil for example where the Pelotas Basin is the classical example of a volcanic passive margin displaying large wedges of SDRs filling the entire basin while the adjacent Santos Basin is a classical example of magma-poor passive margin (Stica et al., 2014). The influence 
of the Paraná-Etendeka Large Igneous Province seems to be only restricted in time and space to the adjacent Pelotas basin. In the northern BoB, the influence of the Kerguelen hotspot is similarly limited to its immediate neighboring domain, perhaps because volcanics of the Kerguelen hotspot were not outcropping there during the uplift of the northern part of the Ninety East ridge (Maurin and Rangin, 2009).

Figures 6,11 and 13 show complementary results concerning the interpretation of both wide-angle reflection seismic and refraction profile 5 and of the coincident MCS profile. Because the geological structure changes along Profile 5, from volcanic features to sills and SDRs on this profile, the location of the base of postrift sediments is clear in some places of MCS Profile 5 (Figures 11 and 13) but unresolved on the wide-angle reflection seismic and refraction Profile 5 (Figure 6). This is essentially due to the fact that refraction data, whatever is the distance between OBSs, cannot resolve the nature of the upper 4-5 km below the basement and consequently where are located the bases of postrift and synrift sediments. On MCS Profile 5, if the base of postrift sediments is well established in some places (Figures 14 and 15), the thickness of synrift sediments and the location of the base of synrift sediments (or the top of the thinned continental crust) are not resolved. However, in the interpretation of the complete set of Bengal MCS data (Rangin et al., 2016 submitted), both the synrift sequence and the associated tilted fault blocks belonging to the brittle thinned continental crust have been identified on most of the MCS profiles.

To summarize, refraction results and deep MCS data bring complementary informations. On Profile 5, refraction data only give informations concerning the nature of the crust (thinned continental crust), the location of the Moho discontinuity and the presence of underplated material at the base of the crust. In contrast, MCS Profile 5 images a volcanic body, sills and SDRs in the upper part of the crust but also sometime the base of postrift sediments. The synrift sediments and tilted fault blocks are not imaged on profile 5 but on other Bengal MCS profiles (Rangin et al., 2016 submitted). Both refraction and MCS data along Profile 5 cannot image the feeding channels of volcanic features (volcanic body, sills and SDRs).

Earlier work has demonstrated that the crust is oceanic south of $15^{\circ} \mathrm{N}$ (Curray et al., 1982; Gopala Rao et al., 1997), suggesting the thinned continental crust might not extend south of $15^{\circ} \mathrm{N}$ latitude. Based on refraction data, a thinned continental crust was identified onshore Bangladesh (Kaila et al., 1992) reaching a thickness of $30 \mathrm{~km}$ south of the Shillong Plateau (Mitra et al., 2006), in the Sylhet Basin, a continental basin located immediately south of the Shillong Plateau (Johnson and Nur Alam, 1991). As the thickness of the crust decreases 
from the Sylhet Basin $(30 \mathrm{~km})$ to the location of our offshore refraction survey $(20 \mathrm{~km}$ near the shelf edge and $10 \mathrm{~km}$ further south at $19^{\circ} \mathrm{N}$ latitude), there is no data, which favor the presence of oceanic crust in between these two locations. Therefore, we suggest that the crust located north of $19^{\circ} \mathrm{N}$ latitude is thinned continental crust up to the latitude of the Shillong Plateau $\left(25^{\circ} \mathrm{N}\right)$ and not oceanic crust as generally quoted in the literature (e. g. Verma and Mukhopadhyay (1977), Uddin and Lundberg (2004)). Between $19^{\circ} \mathrm{N}$ and $15^{\circ} \mathrm{N}$ latitude, the crust is of unknown nature but could be still thinned continental crust, at least just south of $19^{\circ} \mathrm{N}$.

\section{Conclusions}

The main conclusions of the processing of three wide-angle seismic reflection and refraction profiles acquired simultaneously with MCS reflection profiles in the northern Bay of Bengal are as follows:

1) The final velocity models show a sedimentary cover thickening from a minimum of $13 \mathrm{~km}$ below the shelf to a minimum of $7 \mathrm{~km}$ towards the southeast. Four distinct sedimentary layers have been modeled with velocities ranging from $1.80 \mathrm{~km} / \mathrm{s}$ to $4.80 \mathrm{~km} / \mathrm{s}$. The green reflector is the top of a thin but highly reflective series of horizons located in the lower part of sedimentary layers and is an indisputable marker well recognized in the whole Bay of Bengal. High seismic velocities are larger than those commonly found for sediments and might correspond to either highly compacted sediments or a hard ground formed during the late Cretaceous drift of the Bengal Basin attached to India with respect to Antarctica and away from any sediment input. All velocity-depth profiles show that the crust is thinned continental crust with a crustal thickness varying between 10 and $20 \mathrm{~km}$ and low velocity gradients comparable to those of thinned continental crust. Because the Moho discontinuity is associated with a mean $7.4-8.1 \mathrm{~km} / \mathrm{s}$ velocity drop and is well defined on refraction data, the $7.4 \mathrm{~km} / \mathrm{s}$ seismic velocities found at the base of the crust represent magmatic underplating probably emplaced during continental extension rather than serpentinized peridotites.

2) Refraction results and deep MCS data bring complementary informations. On Profile 5, refraction data only give informations concerning the nature of the crust (thinned continental crust), the location of the Moho discontinuity and the presence of underplated material at the base of the crust. In contrast, in the upper part of the crust, MCS Profile 5 images a volcanic body, sills and SDRs located in the close vicinity of the Ninety East ridge, and also sometime the base of postrift sediments. The synrift sediments and tilted fault blocks 
are not imaged on MCS profile 5. Both refraction and MCS data along Profile 5 cannot image the feeding channels of volcanic features (volcanic body, sills and SDRs). The imaged volcanic intrusion as well as adjacent sills and SDRs located nearby appear to have been emplaced before the emplacement of the green reflector dated Campanian to Paleocene, suggesting they were emplaced at the same time that the volcanic intrusion, when the Kerguelen hotspot was nearby.

3) We conclude that the crust in the northern Bay of Bengal is thinned continental crust intruded by volcanic products with the presence of a minor amount of underplating material at its base. Such a crustal structure probably extends from the northern Bay of Bengal $\left(19^{\circ} \mathrm{N}\right)$ to the Shillong Plateau $\left(25^{\circ} \mathrm{N}\right)$. These new findings are critical for the oil and gas exploration presently very active in the northern Bay of Bengal area.

\section{Acknowledgments}

This work was performed under the responsibility of the Chaire de Géodynamique du Collège de France in Aix-en Provence, in the framework of a cooperative scientific agreement between Collège de France and Total Exploration. The Bengal cruise was conducted under the leadership of Claude Rangin. We thank Chao-Shing Lee of the National Taiwan University who provided nine OBSs for the refraction experiment and the Bangladesh Navy, which helped us to deploy them on a Navy vessel. Yuan-Ping Huang benefited of a National Research Council grant, which supported a one-year training at Ifremer under Frauke Klingelhoefer supervision. We thank the two anonymous reviewers and particularly the Associate Editor Bernard Colletta for their careful and very useful reviews.

\section{References}

Auffret, Y., P. Pelleau, F. Klingelhoefer, L. Géli, J. Crozon, J.-Y. Lin and J.-C. Sibuet (2004). MicrOBS: A new generation of ocean bottom seismometer. first break, 22, 41-47.

Canales, J. P., R. S. Detrick, J. Lin and J. A. Collins (2000). Crustal and upper mantle seismic structure beneath the rift mountains and across a nontransform offset at the Mid-Atlantic Ridge $\left(35^{\circ}\right.$ N). J. Geophys. Res., 105, 2699-2719.

Caress, D. W., M. McNutt, R. S. Detrick and J. C. Mutter (1995). Seismic imaging of hotspotrelated crustal underplating beneath the Marquesas Islands. Nature, 373, 600-603.

Christensen, N. I. and W. D. Mooney (1995). Seismic velocity structure and composition of 
the continental crust: A global view. Journal of Geophysical Research, 100, 9761-9788.

Cohen, J. K. and J. W. Stockwell (2003). Seismic Unix Release 37: A free package for seismic research and processing. Center for Wave Phenomena, Colorado School of Mines, $\mathrm{CO}$.

Curray, J. R. (1994). Sediment volume and mass beneath the Bay of Bengal. Earth and Planetary Science Letters, 125(1-4), 371-383.

Curray, J. R., F. J. Emmel, D. G. Moore and R. W. Raitt (1982). Structure, tectonics and geological history of the northeastern Indian Ocean. The Ocean Basins and Margins: The Indian Ocean. A. E. M. Nairn and F. G. Stehli. New-York, Plenum Press. 6, 399-450.

Curray, J. R. and D. G. Moore (1971). Growth of the Bengal deep-sea fan and denudation in the Himalayas. Geological Society of America Bulletin, 82, 563-572.

Dean, S. M., T. A. Minshull, R. B. Whitmarsh and K. E. Louden (2000). Deep structure of the ocean-continent transition in the southern Iberia Abyssal Plain from seismic refraction profiles: The IAM-9 transect at 40² $20^{\prime} \mathrm{N}$. Journal of Geophysical Research, 105, 5859-5886. doi: 10.1029/1999JB900301.

Desa, M., M. V. Ramana and T. Ramprasad (2006). Seafloor spreading magnetic anomalies south off Sri Lanka. Marine Geology, 229, 227-240.

Farnetani, C. G., M. A. Richards and M. S. Ghiorso (1996). Petrological models of magma evolution and deep crustal structure beneath hotspots and flood basalt provinces. Earth Planet. Sci. Lett., 143, 81-94.

Funk, T., H. R. Jackson, K. E. Louden, S. A. Dehler and Y. Wu (2004). Crustal structure of the northern Nova Scotia rifted continental margin (Eastern Canada). J. Geophys. Res., 109(B9), doi: 10.1029/2004JB003008.

Gopala Rao, D., K. S. Krishna and D. Sar (1997). Crustal evolution and sedimentation history of the Bay of Bengal since the Createous. J. Geophys. Res., 102, 17747-17768. doi: 10.1029/96JB01339.

Johnson, S. Y. and A. M. Nur Alam (1991). Sedimentation and tectonics of the Sylhet trough, Bangladesh. Geological Society of America Bulletin, 103, 1513-1527.

Kaila, K. L., P. R. Reddy, D. M. Mall, N. Venkateswarlu, V. G. Krishna and A. S. S. S. R. S. Prasad (1992). Crustal structure of the west Bengal basin, India, from deep seismic sounding investigations. Geophys. J. Int., 111, 45-66. doi: 10.1111/j.1365-246X.1992.tb00554.x.

Klingelhoefer, F., R. A. Edwards, R. W. Hobbs and R. W. England (2005). Crustal structure of the NE Rockall Trough from wide-angle seismic data modeling. J. Geophys. Res., 110(B11105), doi: 10.1029/2005JB003763.

Lau, K. W. H., K. E. Louden, S. Deemer, J. Hall, J. R. Hopper, B. E. Tucholke, W. S. Holbrook and H. C. Larsen (2006). Crustal structure across the Grand Banks-Newfoundland Basin Continental Margin- II. Results from a seismic reflection profile. Geophysical Journal 
International, 167, 157-170. doi: 10.1111/j.1365-246X.2006.02989.x.

Ludwig, J. W., J. E. Nafe and C. L. Drake (1970). Seismic refraction. The Sea. New-York, John Wiley. 4, 55-84.

Mall, D. M., V. K. Rao and P. R. Reddy (1999). Deep sub-crustal features in the Bengal Basin: Seismic signatures for plume activity. Geophys. Res. Lett., 26(16), 2545-2548.

Maurin, T. and C. Rangin (2009). Impact of the $90^{\circ} \mathrm{E}$ ridge at the Indo-Burmese subduction zone imaged from deep seismic reflection data. Marine Geology, 260, 143-155. doi: 10.1016j.margeo.2009.07.015.

Mitra, S., N. Hazarika, K. Priestley and V. K. Gaur (2006). Lithospheric structure across the eastern Himalayan collision from the Bengal basin to southern Tibet. J. Asian Earth Sci., 26, 151.

Moore, D. G., J. R. Curray, R. W. Russell W. Raitt and F. J. Emmel (1974). Stratigraphicseismic section correlations and implications to Bengal fan history. Initial Reports of the Deep Sea Drilling Project. C. C. von der Borch and J. G. Sclater. Washington (U.S. Government Printing Office). 22, 403-412.

Morgan, J. V. and P. J. Barton (1990). A geophysical study of the Hatton Bank volcanic margin: A summary of the results from a combined seismic, gravity and magnetic experiment. Tectonophysics, 173, 517-526.

Muller, R. D., J.-Y. Royer and L. A. Lawver (1993). Revised plate motions relative to the hotspots from combined Atlantic and Indian Ocean hotspot tracks. Geology, 16, 275-278.

Naini, B. R. and R. Leyden (1973). A wide angle seismic reflection and refraction study. J. Geophys. Res., 78(35), 8711-8720. doi: 10.1029/JB078i035p08711.

Radhakrishna, M., C. Subrahmanyam and T. Damodharan (2010). Thin oceanic crust below Bay of Bengal inferred from 3-D gravity interpretation. Tectonophysics, 493, 93-105.

Rangin, C., T. Maurin and F. Masson (2013). Combined effects of Eurasia/Sunda oblique convergence and East-Tibetan crustal flow on the active tectonics of Burma. Journal of Asian Earth Sciences, 76, 185-194. doi: 10.1016/j.jseaes.2013.05.018.

Rangin, C., J.-C. Sibuet and T. Maurin (2016 submitted). Structure of the northern Bengal basin offshore Bangladesh: Evidences from new multi-channel seismic data. Marine and Petroleum Geology.

Sibuet, J.-C., V. Louvel, R. B. Whitmarsh, R. S. White, S. J. Horsefield, B. Sichler, P. Léon and M. Recq (1995). Constrainsts on rifting processes from refraction and deep-tow magnetic data: The example of the Galicia continental margin (West Iberia). Rifted ocean-continent boundaries. E. Banda, M. Torné and M. Talwani, NATO ASI Series, series C, Mathematical and Physical Sciences. 463, 197-217.

Stica, J. M., P. V. Zalán and A. L. Ferrari (2014). The evolution of rifting on the volcanic margin of the Pelotas Basin and the contextualization of the Paraná-Etendeka LIP in the 
separation of Gondwana in the South Atlantic. Marine and Petroleum Geology, 50, 1-21. http://dx.doi.org/10.1016/j.marpetgeo.2013.10.015.

Stockwell, J. W. (1999). The CWP/SU: Seismic Unix Package. Computers and Geosciences, 25(4), 415-419.

Subrahmanyam, C. and R. N. Singh (1992). Geotectonics of the Bay of Bengal. Indian J. of Pet. Geol., 1, 161-180.

Uddin, A. and L. Lundberg (2004). Miocene sedimentation and subsidence during continentcontinent collision, Bengal basin, Bangladesh. Sedimentary Geology, 164, 131-146.

Verma, R. K. and M. Mukhopadhyay (1977). An analysis of the gravity field in Northeastern India. Tectonophysics, 42(2-4), 283-317. doi: 10.1016/0040-1951(77)90171-8.

Watts, A. B., U. S. ten Brink, P. Buhl and T. M. Brocher (1985). A multichannel seismic study of lithospheric flexure across the Hawaiian-Emperor seamount chain. Nature, 315, 105111.

White, R. S., D. McKenzie and K. O'Nions (1992). Oceanic crustal thickness from seismic measurements and rare earth element inversions. Journal of Geophysical Research, 97, 1968319715.

Whittaker, J. M., J. A. Halpin, S. E. Williams, L. S. Hall, R. Gardner, M. E. Kobler, N. R. Daczko and R. D. Müller (2013). Tectonic evolution and continental fragmentation of the southern west Australian margin. West Australian Basins Symposium 2013, Perth, WA.

Zelt, C. A. (1999). Modelling strategies and model assessment for wide-angle seismic traveltime data. Geophys. J. Int., 139, 183-204.

Zelt, C. A. and P. J. Barton (1998). Three-dimensional seismic refraction tomography: A comparison of two methods applied to data from the Faroe Basin. J. Geophys. Res., 103, 7187-7210.

Zelt, C. A. and R. B. Smith (1992). Seismic travel time inversion for 2-D crustal velocity structure. Geophysical Journal International, 108, 16-31.

\section{Legend of Figures}

Figure 1: Main kinematic plates and tectonic features in and around the Bay of Bengal.

Magnetic lineations and their identifications in black (Desa et al., 2006) and inferred fracture zones in the Bay of Bengal (Desa et al., 2006). Black arrows show the motion of India and India-Australia plates with respect to the Sunda plate (IN/SU and IA/SU). In black and red, MCS lines acquired during the Bengal cruise. Refraction data were collected along the black lines and also appear in Figure 2. 217: DSDP Site 217. 
Figure 2: Location on the bathymetric map of the three OBS profiles acquired during the Bengal cruise in black. Black dots are locations of the nine OBSs on each refraction profile. Other MCS lines acquired during the Bengal cruise but without refraction data are in red as well as their numberings.

Figure 3: (a) Data from the vertical geophone section from OBS 1 on Profile 11. The data are displayed with a gain proportional to the source-receiver offset and are reduced at a velocity of $6 \mathrm{~km} / \mathrm{s}$. (b) Synthetic seismograms calculated from the velocity model for the same station using the finite difference modeling code of the Seismic Unix package (Stockwell, 1999; Cohen and Stockwell, 2003). The synthetic seismograms are calculated every $100 \mathrm{~m}$ with a source frequency centered around $12 \mathrm{~Hz}$. (c) Ray-tracing of OBS 1 in the final model.

Figure 4: (a) Data from the vertical geophone section from OBS 5 on Profile 5. The gain, filter, and scaling are the same as those applied in Figure 3. (b) Corresponding synthetic seismograms calculated from the model using the same method as that in Figure 3. (c) Raytracing of OBS 5 in the final model.

Figure 5: Results from tomographic modeling (FAST) of the first arrivals along the three profiles. Positions of instruments on the seafloor are marked by red circles. Black lines represent layer boundaries from the forward modeling.

Figure 6: Final forward velocity model (Rayinvr) for all three wide-angle seismic reflection and refraction models. Contour interval is $0.25 \mathrm{~km} / \mathrm{s}$ (blue lines) and layer boundaries are marked by black lines. Positions of instruments on the seafloor are marked by red circles. Dark areas are constrained by ray paths. In dark green, postrift section, undifferentiated synrift and thinned continental crust, underplating material and upper mantle.

Figure 7: Arrivals from sedimentary and crustal layers picked from OBS data. Ray paths for every $40^{\text {th }}$ ray separately for diving (right) and reflected (left) rays for all three profiles. Below each profile, corresponding travel-time picks and predicted arrivals.

Figure 8: Ray density for the three wide-angle seismic reflection and refraction profiles. Model boundaries from forward modeling are marked by black lines and positions of seafloor instruments by red circles. 
Figure 9: Resolution for the three profiles. Areas with resolution parameters larger than 0.5 can be considered as well constrained. Model boundaries from forward modeling are marked by black lines and locations of OBSs are marked by red dots.

Figure 10: Results of the gravity modeling for the three profiles. Upper panels show the measured gravity anomaly (dotted lines) and the predicted anomaly (continuous lines) from velocity models. Lower panels show model boundaries from forward modeling marked by black lines and locations of OBSs marked by red dots. Mean upper and lower layer densities in $\mathrm{g} / \mathrm{cm}^{3}$ are annotated along each profile.

Figure 11: Data sections from the three seismic reflection profiles 2, 11 and 5. Layers from forward modeling converted to two-ways travel-time (TWTT) are represented by red lines. Locations of OBSs are marked by red dots. In dark green, postrift section overlying the undifferentiated synrift and thinned continental crust.

Figure 12: 1-D velocity depth profiles (thin lines) every ten kilometers for the three profiles. Velocity bounds for 59-127 Ma old oceanic crusts are in light blue (White et al., 1992). Velocity bounds for exhumed, serpentinized upper mantle are in dark blue (Dean et al., 2000). The grey line is the mean velocity crust for extended continental crust (Christensen and Mooney, 1995). Crustal velocities are assumed to start at the top of the crust (reflector located beneath the green reflector).

Figure 13: MCS Profile 5 and interpretation. The red dashed line is the Moho determined by wide-angle seismic reflection and refraction data. Location of the two blow-ups, which appear in the following figures.

Figure 14: Zoom of a portion of Profile 5 showing a 40-km wide volcanic intrusion emplaced on top of the thinned continental crust. Upper panel: true amplitude recovery and automatic gain control (AGC). Middle panel: automatic gain control (AGC). Lower panel: Interpretation. The green reflector is dated Maastrichtian (70 Ma) and marks the end of the emplacement of the volcanic body. Black arrows: onlaps on top of the green reflector. A significant amount of postrift sediments $(\sim 1.5 \mathrm{~s}$ TWTT) exists below the green reflector. 
Figure 15: Zoom of a portion of Profile 5 showing SDRs. Upper panel: true amplitude recovery and automatic gain control (AGC). Middle panel: automatic gain control (AGC). Lower panel: Interpretation. The geometry of the dipping reflectors shows a divergent system of reflectors dipping to the southwest without onlaps between these reflectors, suggesting the existence of SDRs and not fan-shaped synrift sediments deposited in between tilted fault blocks. 


\begin{tabular}{|c|c|c|c|c|}
\hline & \multicolumn{2}{|c|}{ Forward model } & \multicolumn{2}{c|}{ Tomographic model } \\
\hline Profile & Number of picks & Rms (s) & Number of picks & Rms (s) \\
\hline 2 & 18,099 & 0.094 & 11,411 & 0.132 \\
\hline 11 & 20,572 & 0.133 & 14,624 & 0.123 \\
\hline 5 & 21,933 & 0.114 & 12,586 & 0.153 \\
\hline
\end{tabular}

Table 1: Number of picks and root-mean-square (rms) error for the three profiles. 


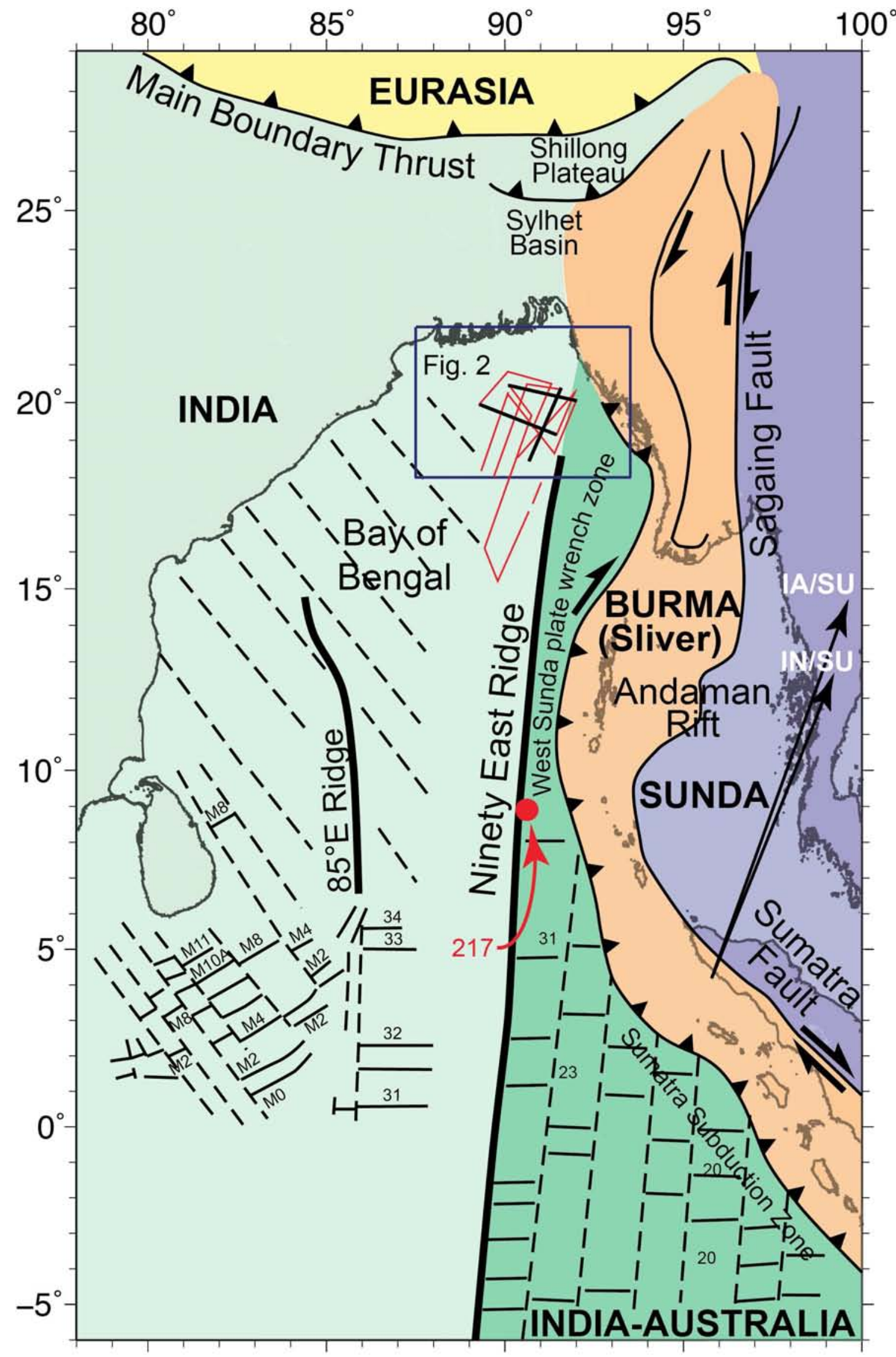

Figure 1 (Sibuet et al.) 


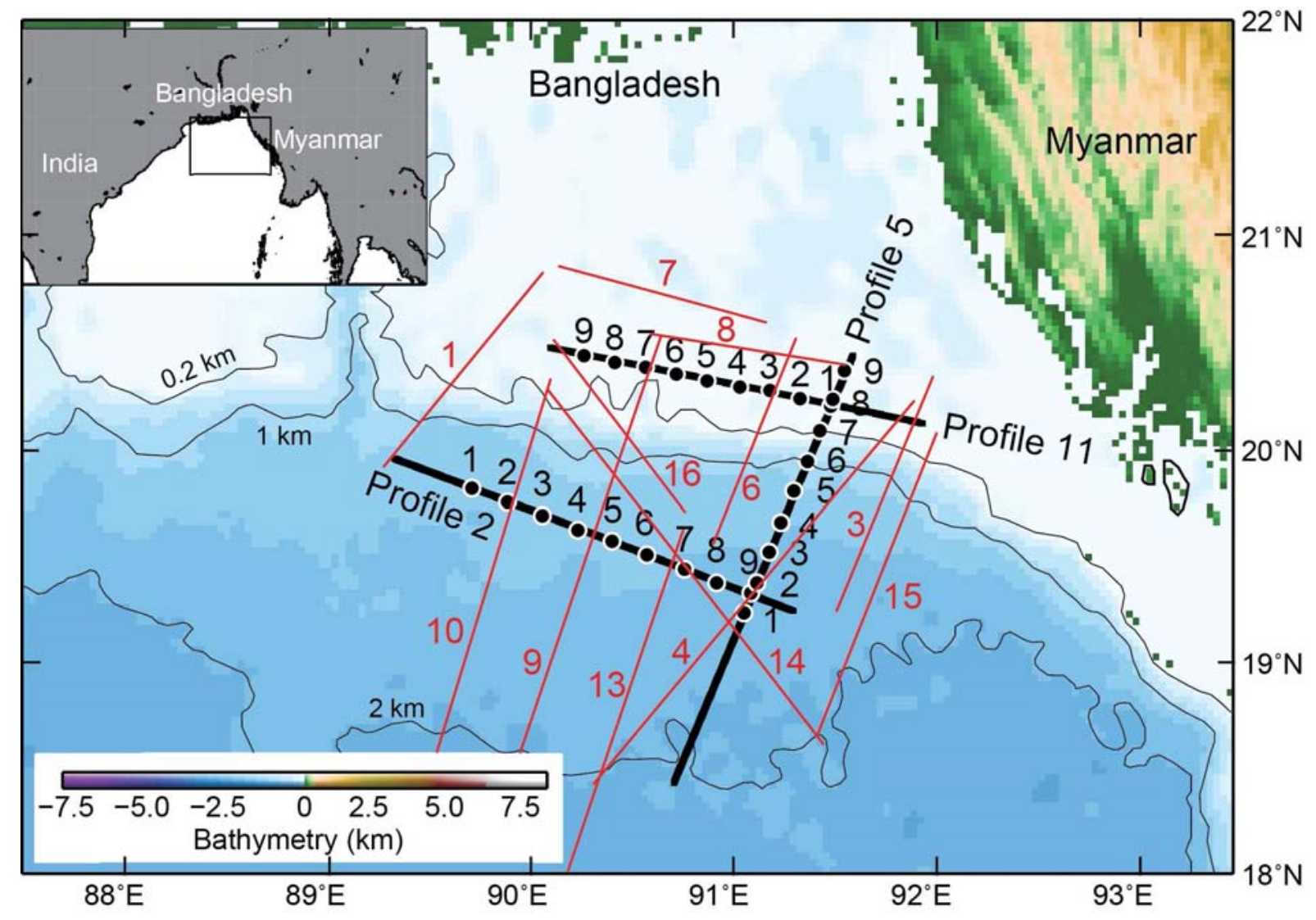

Figure 2 (Sibuet et al.) 

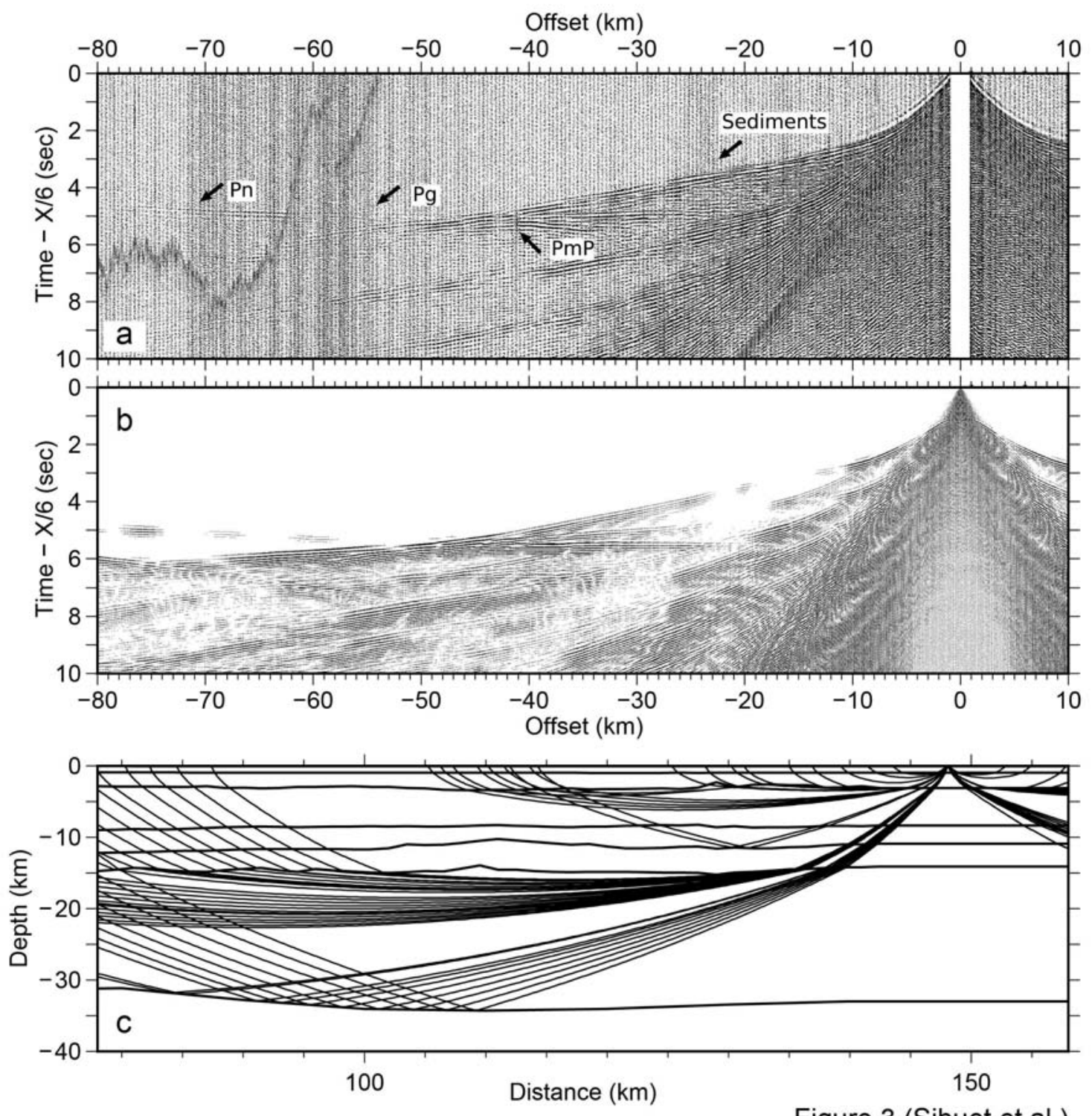

Figure 3 (Sibuet et al.) 

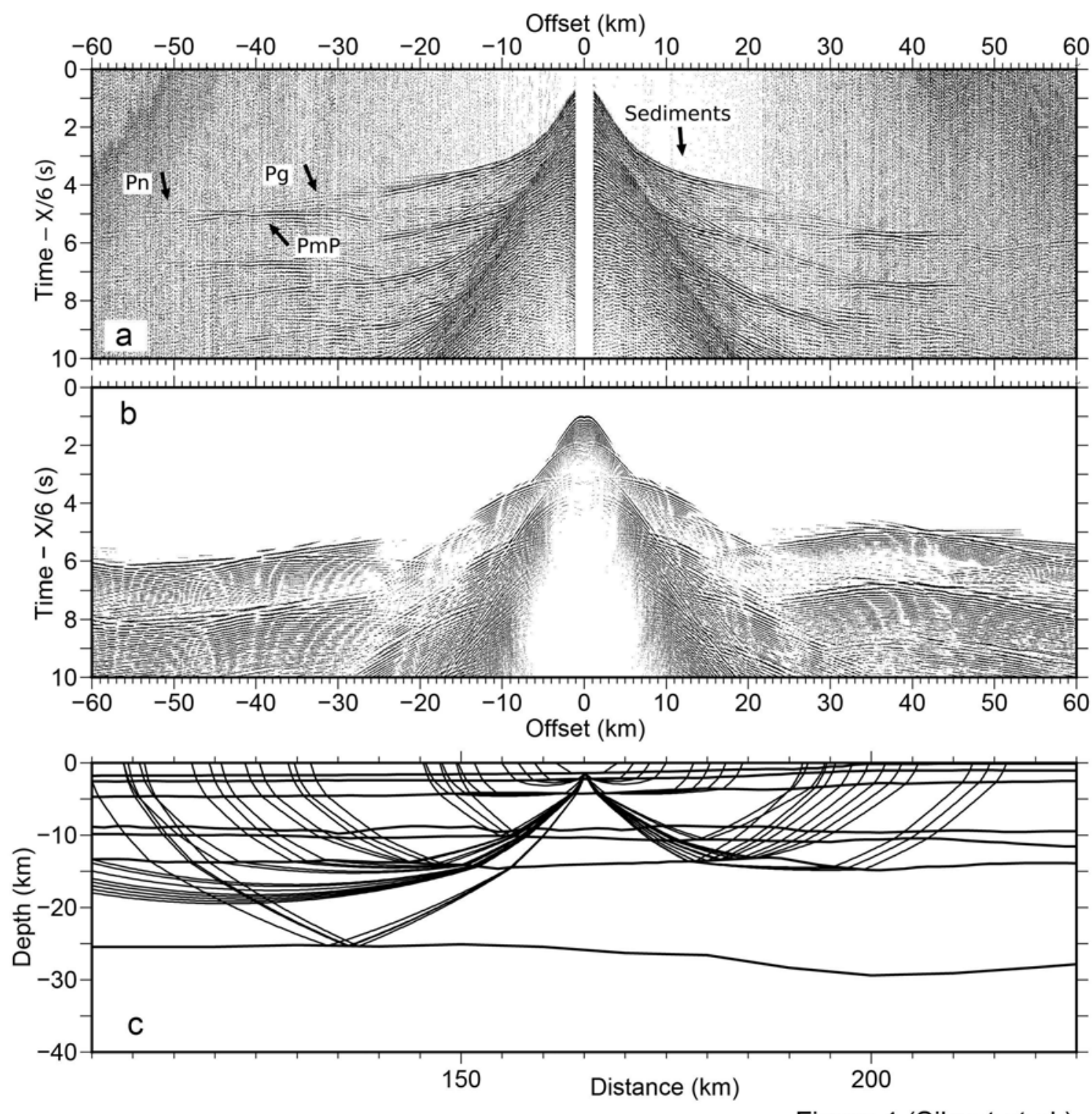

Figure 4 (Sibuet et al.) 

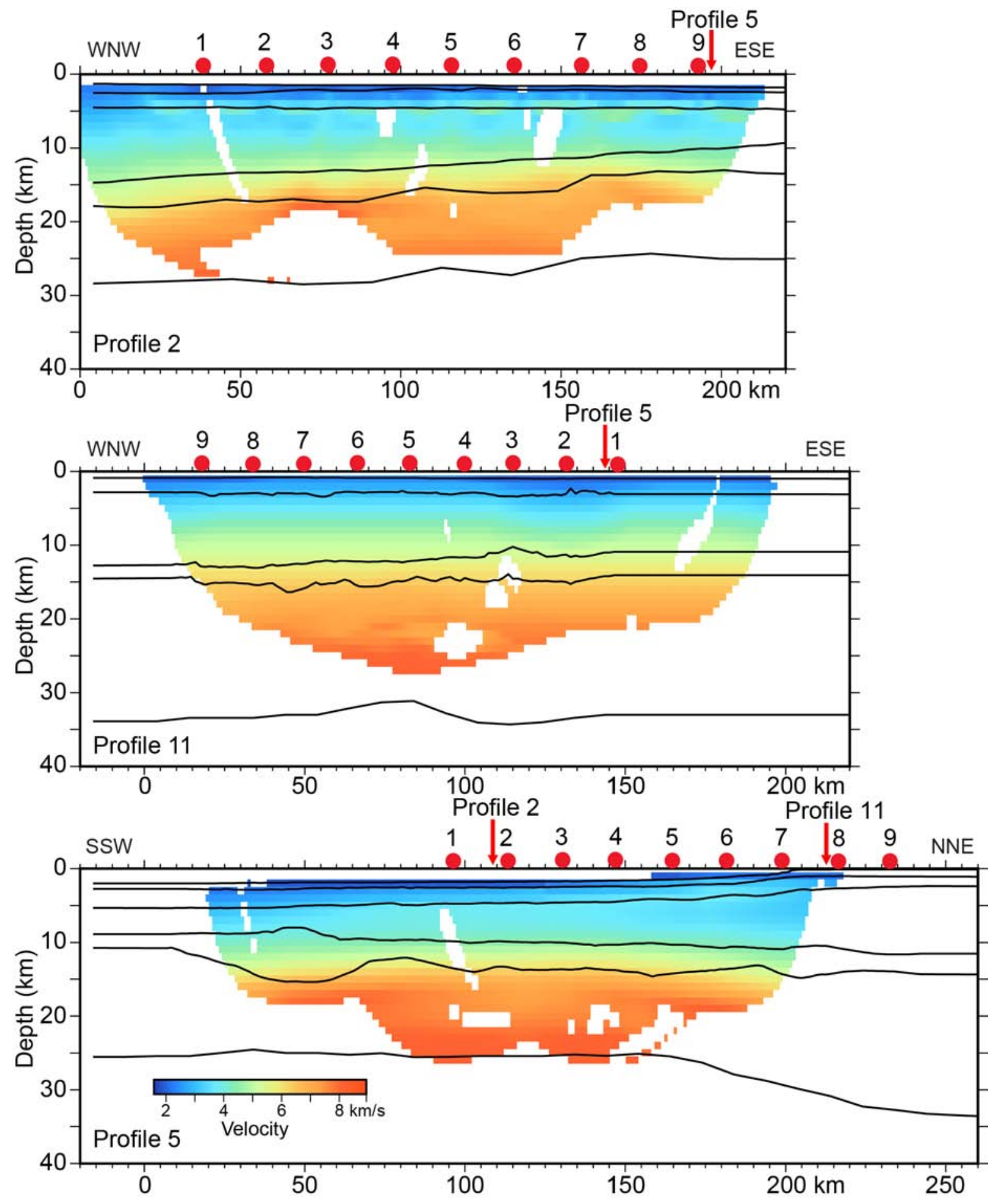

Figure 5 (Sibuet et al.) 


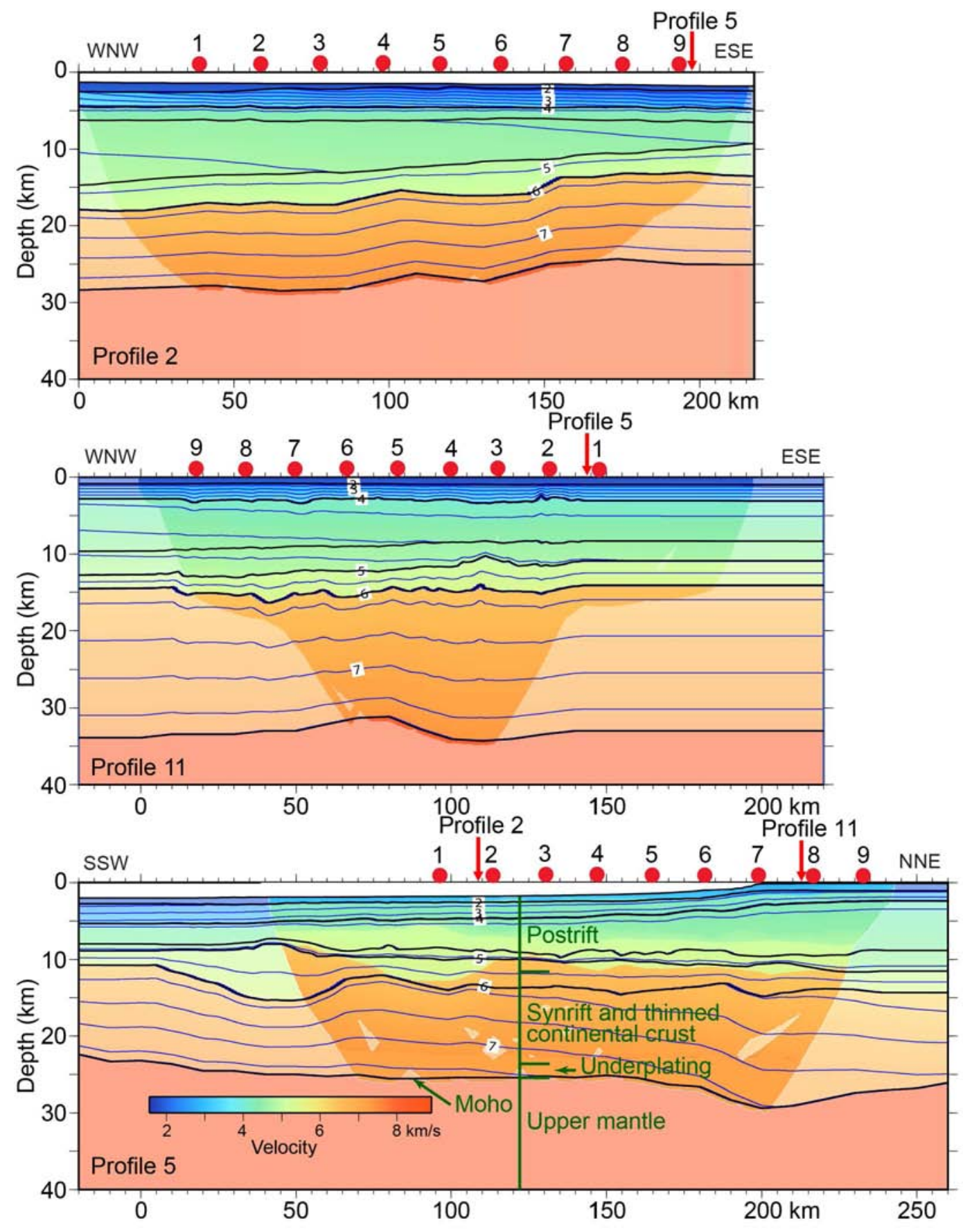

Figure 6 (Sibuet et al.) 

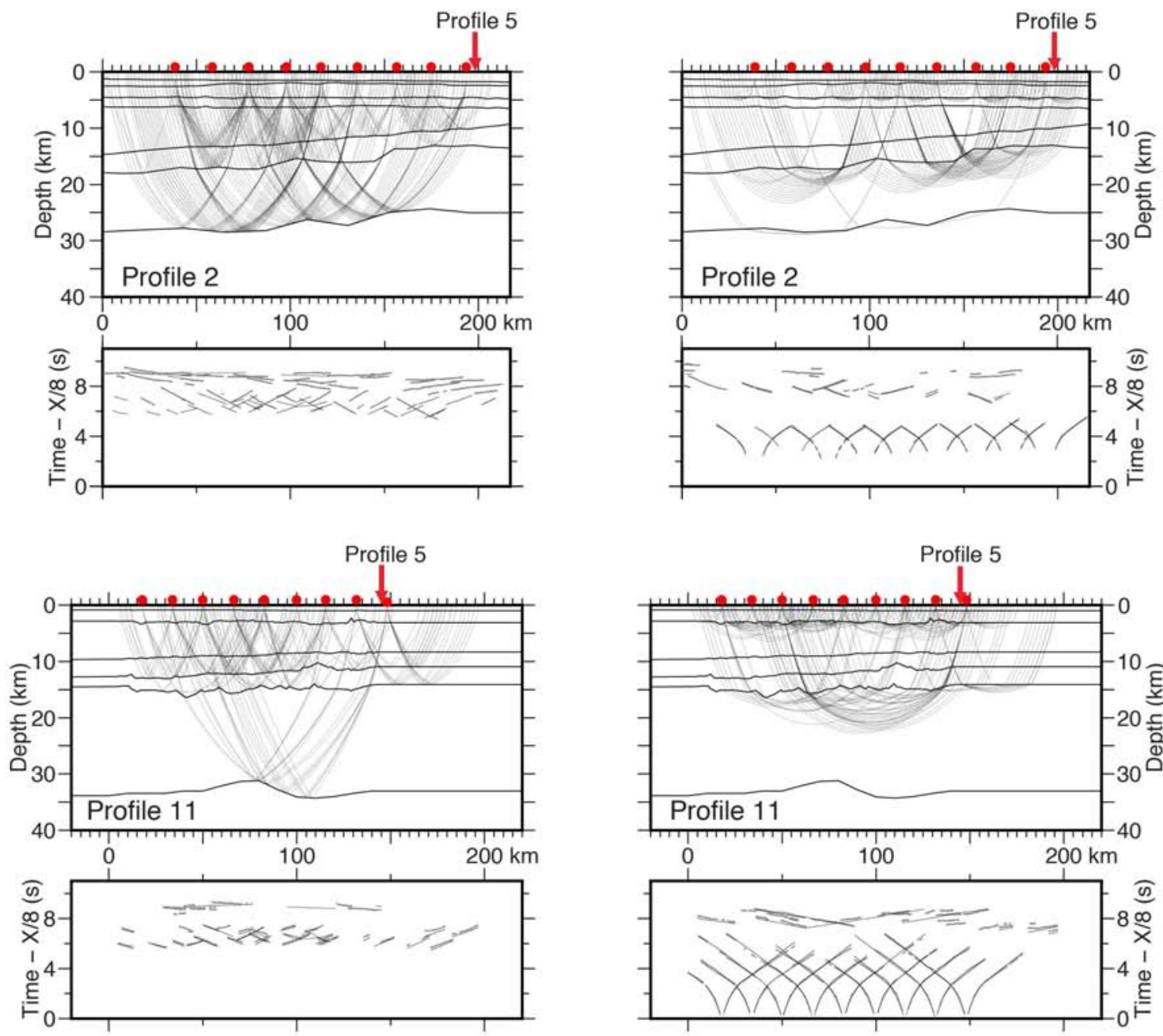

Profile 5
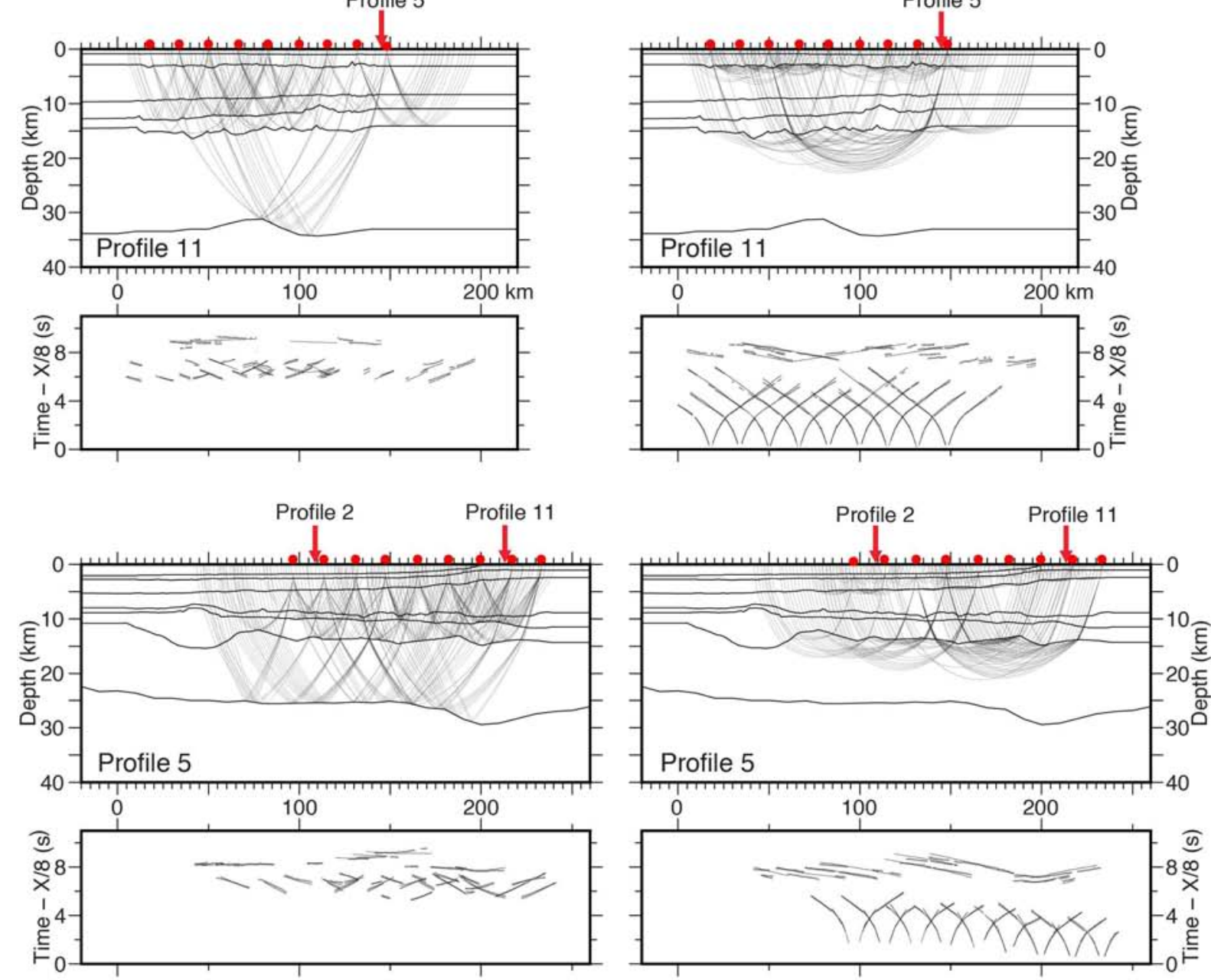

Figure 7 (Sibuet et al.) 

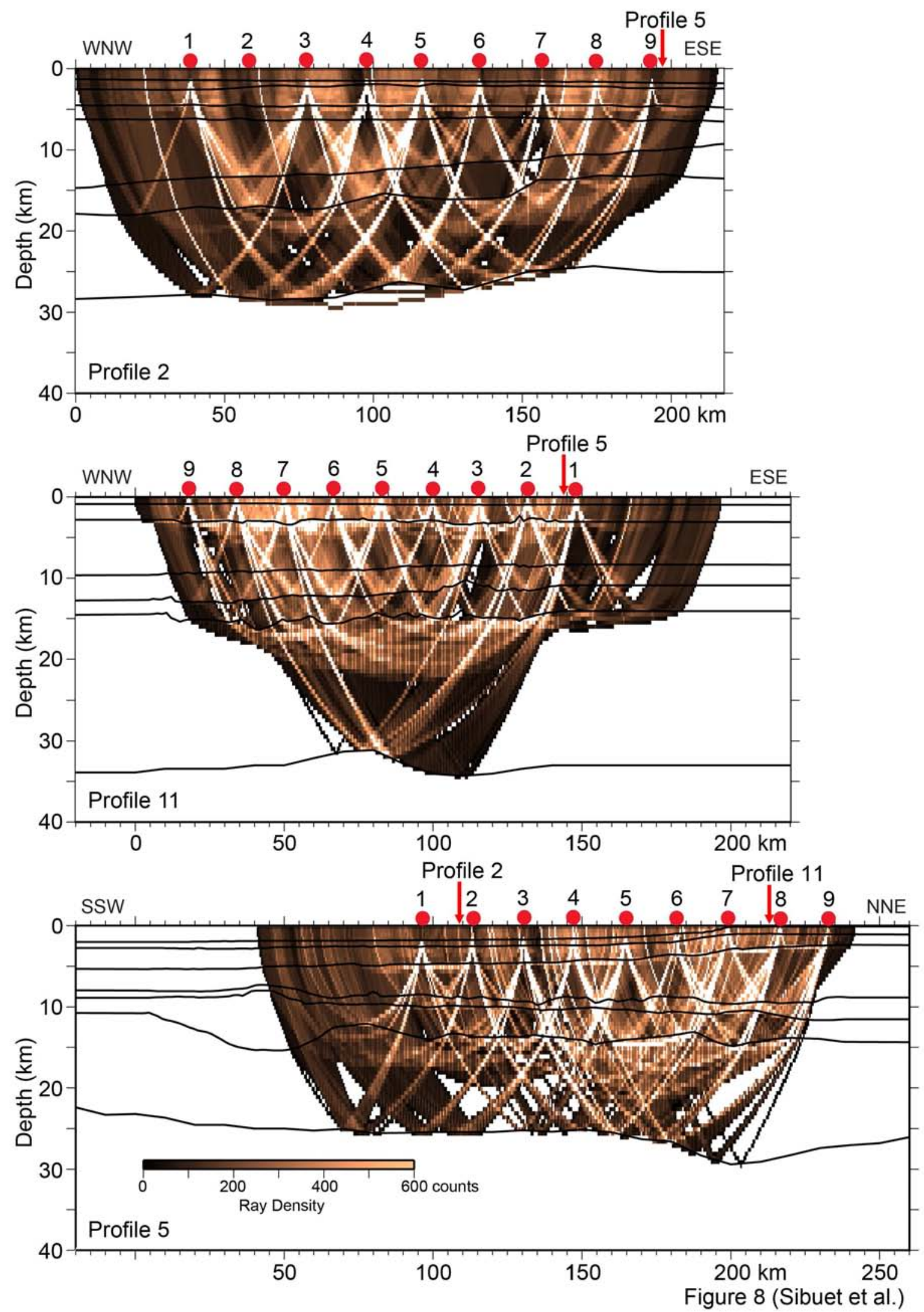

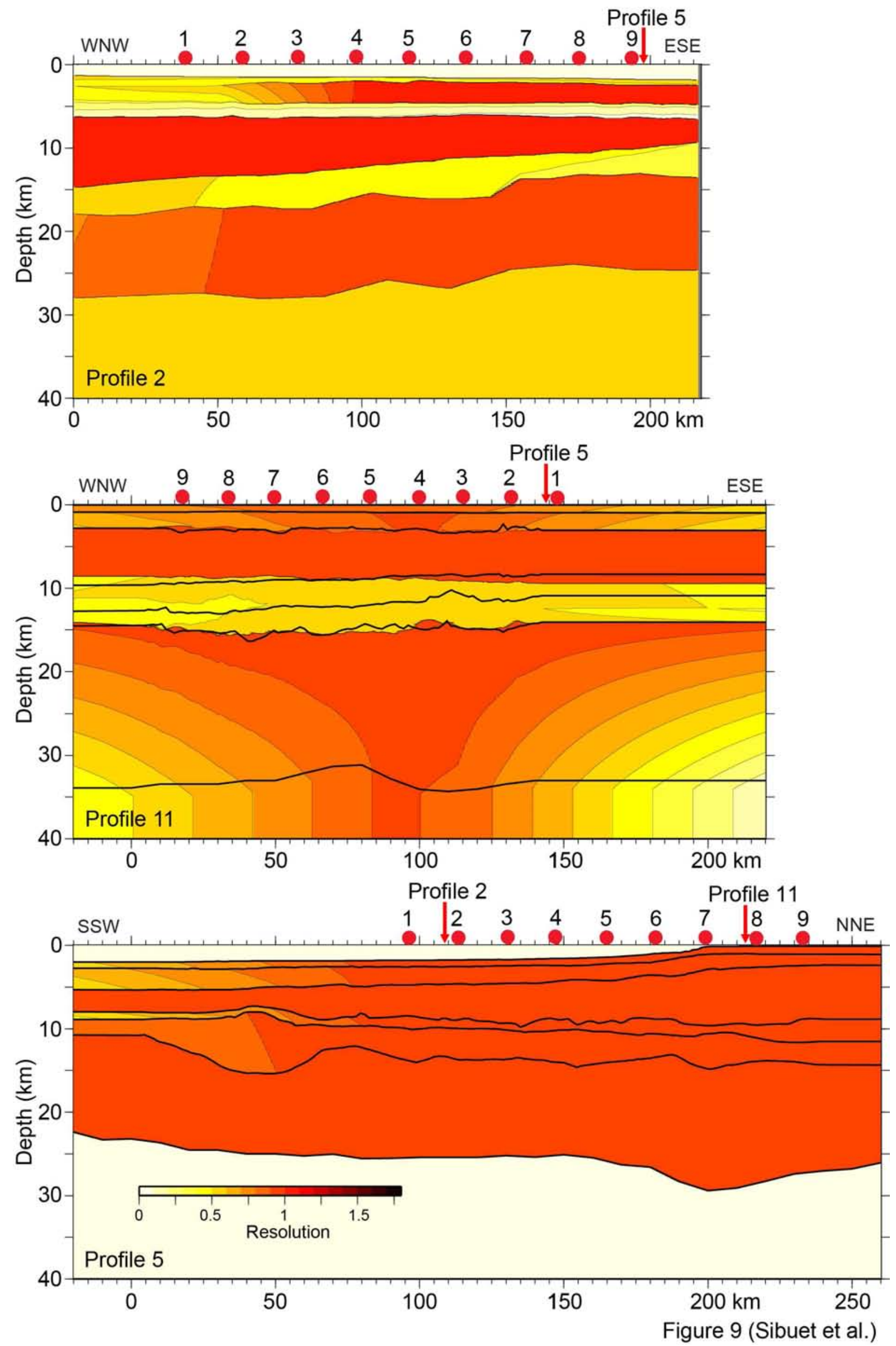

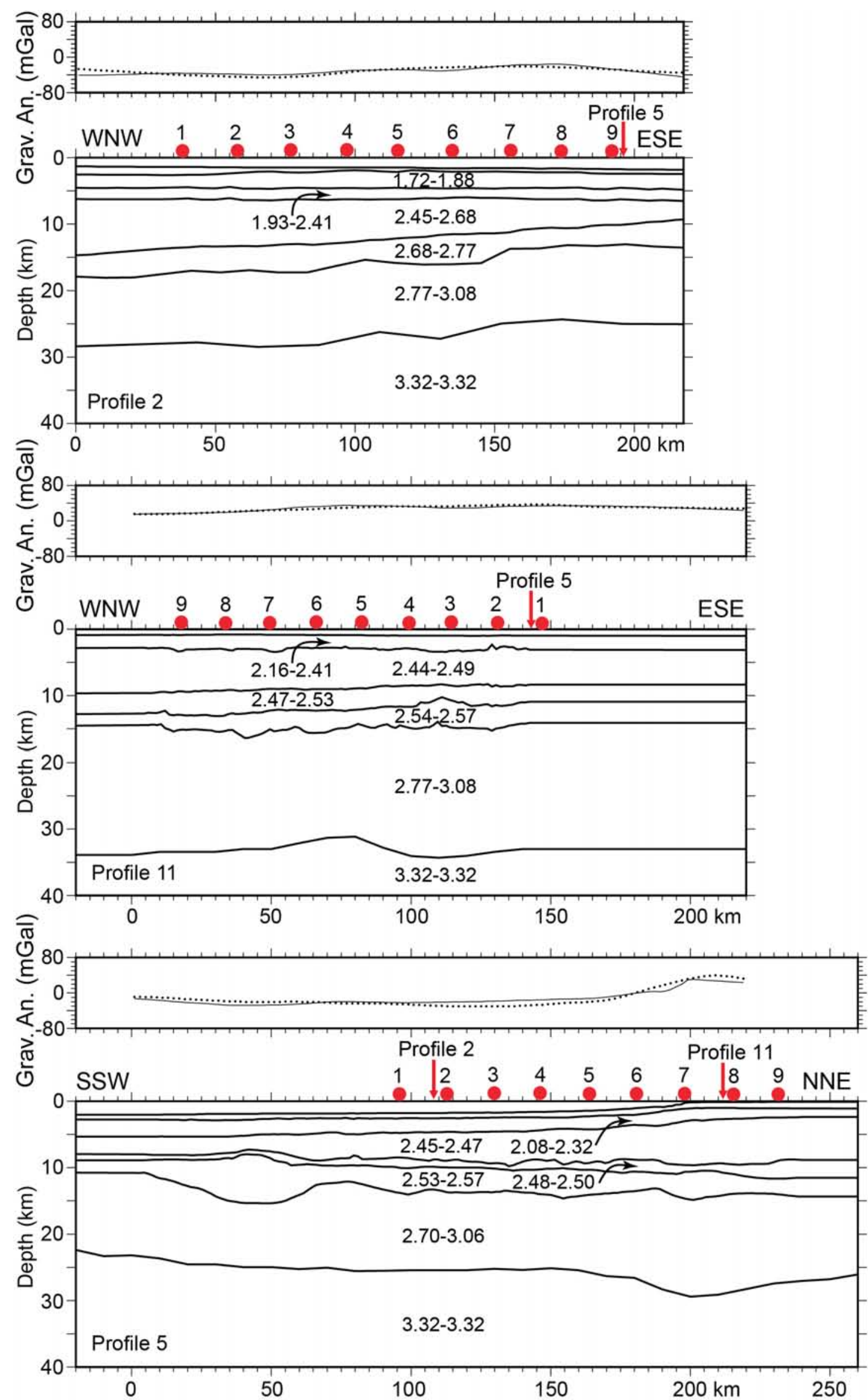

Figure 10 (Sibuet et al.) 

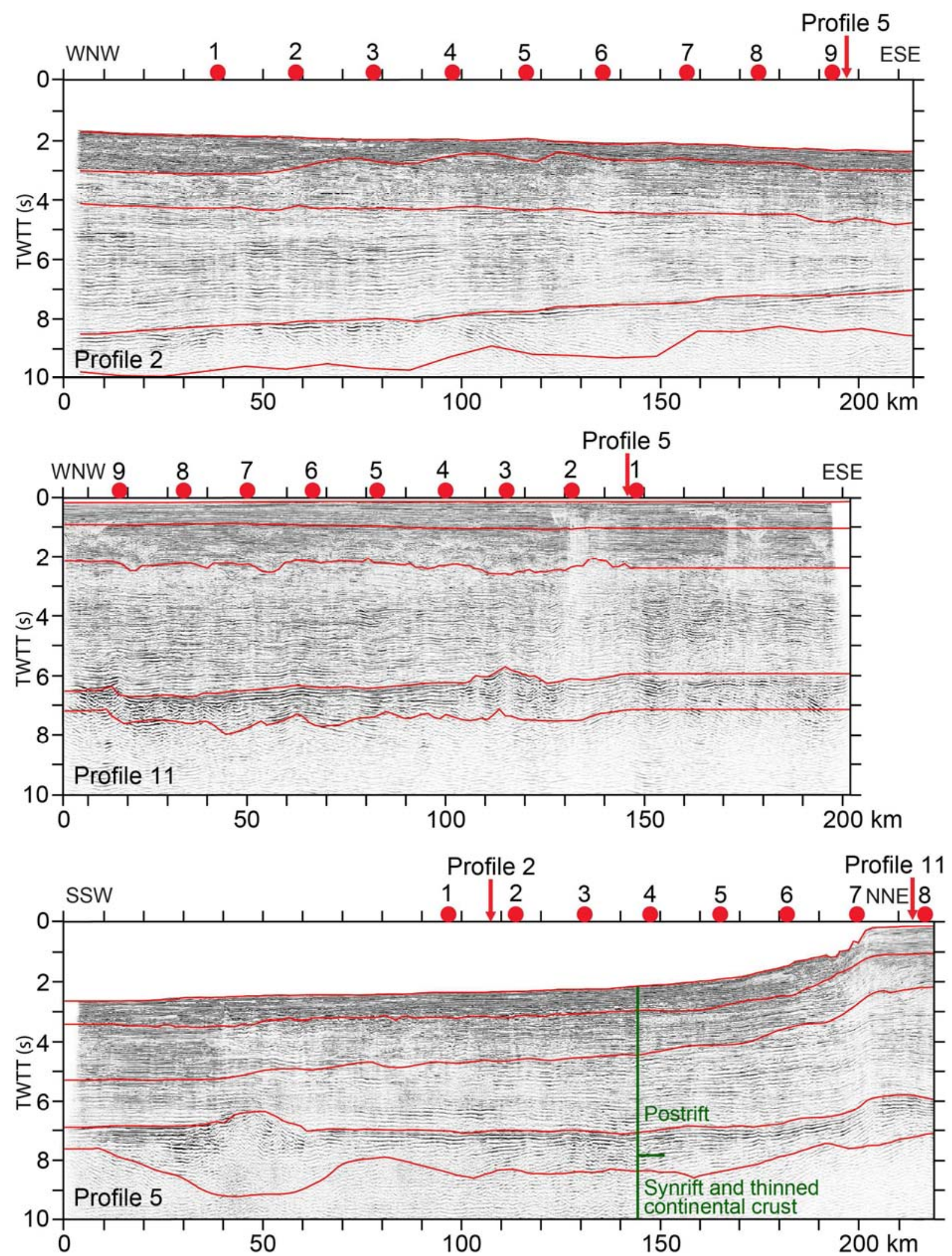

Figure 11 (Sibuet et al.) 

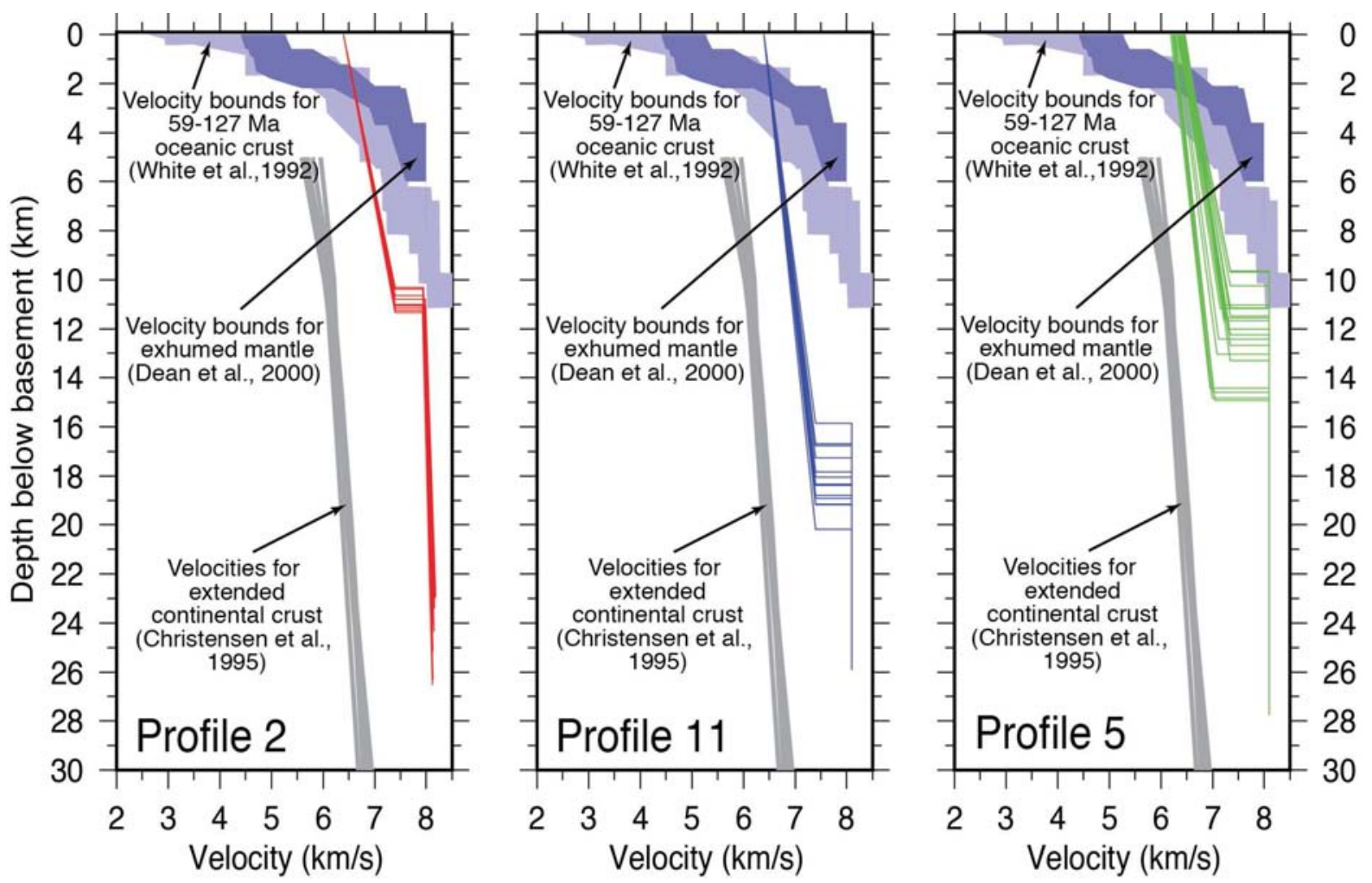

Figure 12 (Sibuet et al.) 


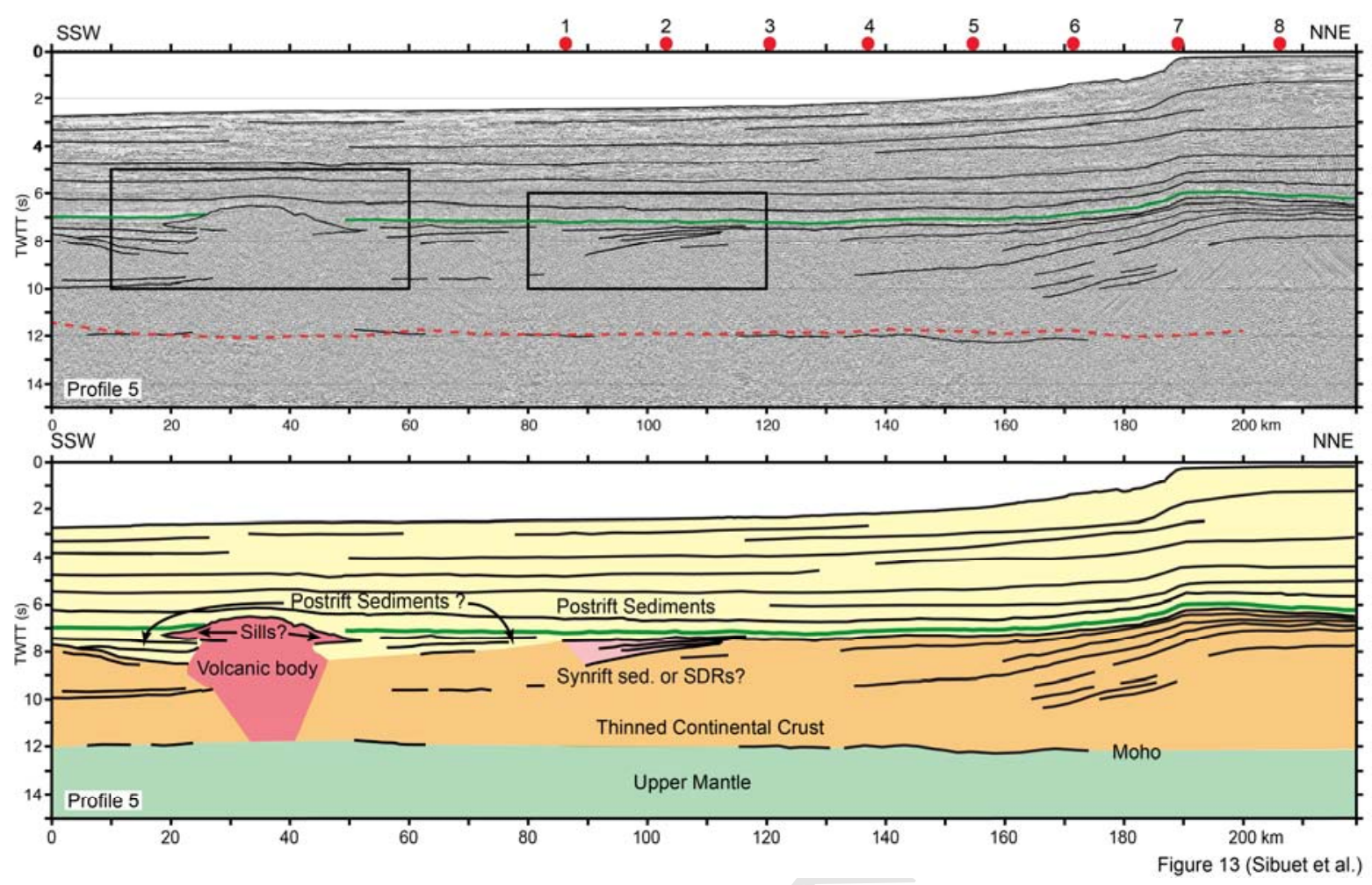



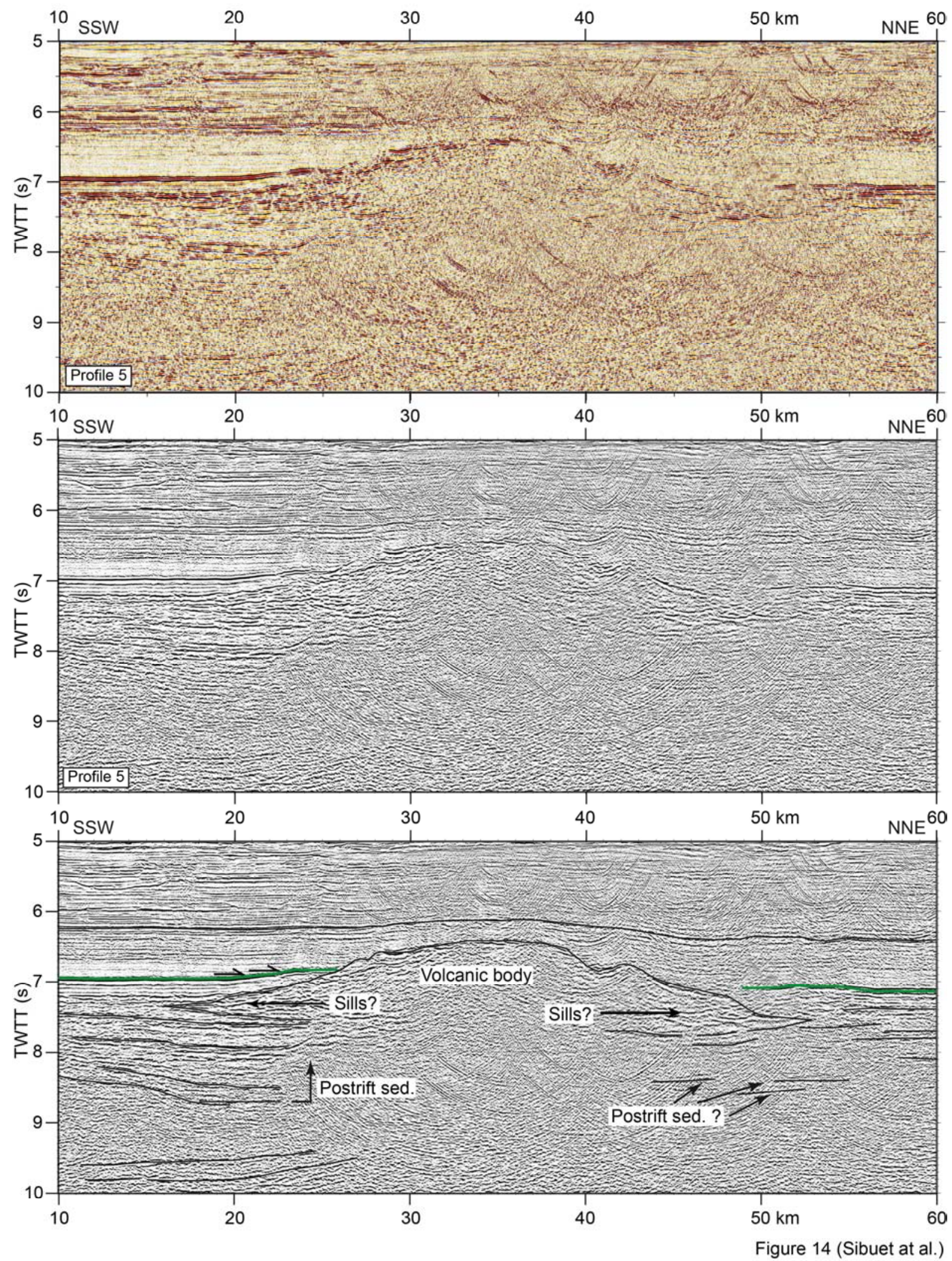


\section{ACCEPTED MANUSCRIPT}
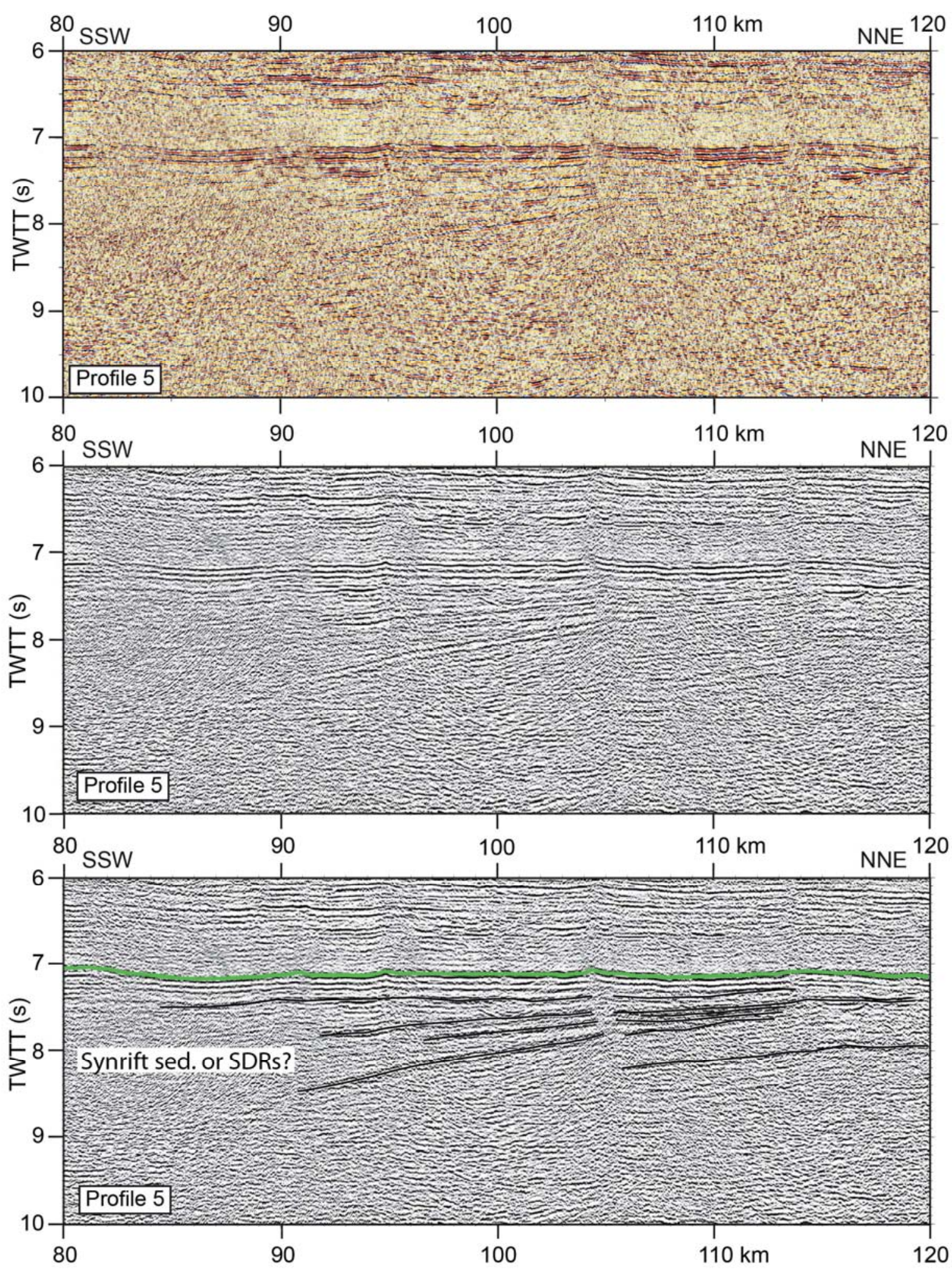

Figure 15 (Sibuet at al.) 
. Refraction velocity models show a sedimentary cover of $13 \mathrm{~km}$ minimum beneath the shelf and $7 \mathrm{~km}$ minimum beneath the deep ocean.

. The crust is thinned continental crust, 10 to $20 \mathrm{~km}$ thick.

. The thinned continental crust is intruded by volcanics, sills and SDRs.

. Seismic velocities of $7.4 \mathrm{~km} / \mathrm{s}$ found at the base of the crust is interpreted as magmatic underplating.

. The thinned continental crust extends from $19^{\circ} \mathrm{N}$ (northern Bay of Bengal) to $25^{\circ} \mathrm{N}$ (Shillong Plateau). 